\title{
NDACC/SAOZ UV-visible total ozone measurements: improved retrieval and comparison with correlative ground-based and satellite observations
}

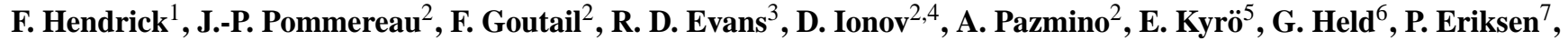 \\ V. Dorokhov ${ }^{8}$, M. Gil ${ }^{9}$, and M. Van Roozendael ${ }^{1}$ \\ ${ }^{1}$ Belgian Institute for Space Aeronomy (BIRA-IASB), Brussels, Belgium \\ ${ }^{2}$ LATMOS, CNRS, and University of Versailles Saint Quentin, Guyancourt, France \\ ${ }^{3}$ Earth System Research Laboratory/Global Monitoring Division, National Oceanic and Atmospheric Administration \\ (NOAA), Boulder, Colorado, USA \\ ${ }^{4}$ Department of Atmospheric Physics, Research Institute of Physics, St. Petersburg State University, St. Petersburg, Russia \\ ${ }^{5}$ Arctic Research Center, Finnish Meteorological Institute (FMI), Sodankyla, Finland \\ ${ }^{6}$ Meteorological Research Institute, Universidade Estadual Paulista, Bauru, S.P., Brazil \\ ${ }^{7}$ Danish Meteorological Institute, Copenhagen, Denmark \\ ${ }^{8}$ Central Aerological Observatory, Moscow, Russia \\ ${ }^{9}$ Instituto de Tecnica Aerospacial (INTA), Torrejón de Ardoz, Spain
}

Received: 16 July 2010 - Published in Atmos. Chem. Phys. Discuss.: 27 August 2010

Revised: 16 June 2011 - Accepted: 20 June 2011 - Published: 24 June 2011

\begin{abstract}
Accurate long-term monitoring of total ozone is one of the most important requirements for identifying possible natural or anthropogenic changes in the composition of the stratosphere. For this purpose, the NDACC (Network for the Detection of Atmospheric Composition Change) UV-visible Working Group has made recommendations for improving and homogenizing the retrieval of total ozone columns from twilight zenith-sky visible spectrometers. These instruments, deployed all over the world in about 35 stations, allow measuring total ozone twice daily with limited sensitivity to stratospheric temperature and cloud cover. The NDACC recommendations address both the DOAS spectral parameters and the calculation of air mass factors (AMF) needed for the conversion of $\mathrm{O}_{3}$ slant column densities into vertical column amounts. The most important improvement is the use of $\mathrm{O}_{3}$ AMF lookup tables calculated using the TOMS V8 (TV8) $\mathrm{O}_{3}$ profile climatology, that allows accounting for the dependence of the $\mathrm{O}_{3}$ AMF on the seasonal and latitudinal variations of the $\mathrm{O}_{3}$ vertical distribution. To investigate their im-
\end{abstract}

Correspondence to: F. Hendrick (franch@oma.be) pact on the retrieved ozone columns, the recommendations have been applied to measurements from the NDACC/SAOZ (Système d'Analyse par Observation Zénithale) network. The revised SAOZ ozone data from eight stations deployed at all latitudes have been compared to TOMS, GOMEGDP4, SCIAMACHY-TOSOMI, SCIAMACHY-OL3, OMITOMS, and OMI-DOAS satellite overpass observations, as well as to those of collocated Dobson and Brewer instruments at Observatoire de Haute Provence $\left(44^{\circ} \mathrm{N}, 5.5^{\circ} \mathrm{E}\right)$ and Sodankyla $\left(67^{\circ} \mathrm{N}, 27^{\circ} \mathrm{E}\right)$, respectively. A significantly better agreement is obtained between SAOZ and correlative reference ground-based measurements after applying the new $\mathrm{O}_{3}$ AMFs. However, systematic seasonal differences between SAOZ and satellite instruments remain. These are shown to mainly originate from (i) a possible problem in the satellite retrieval algorithms in dealing with the temperature dependence of the ozone cross-sections in the UV and the solar zenith angle (SZA) dependence, (ii) zonal modulations and seasonal variations of tropospheric ozone columns not accounted for in the TV8 profile climatology, and (iii) uncertainty on the stratospheric ozone profiles at high latitude in the winter in the TV8 climatology. For those measurements mostly sensitive to stratospheric temperature like TOMS, OMI-TOMS, Dobson and Brewer, or to SZA like

Published by Copernicus Publications on behalf of the European Geosciences Union. 
SCIAMACHY-TOSOMI, the application of temperature and SZA corrections results in the almost complete removal of the seasonal difference with SAOZ, improving significantly the consistency between all ground-based and satellite total ozone observations.

\section{Introduction}

For more than two decades, stratospheric ozone and related trace gases such as $\mathrm{NO}_{2}, \mathrm{BrO}$, and $\mathrm{OClO}$ have been monitored at a number of stations belonging to the Network for the Detection of Atmospheric Composition Change (NDACC) using ground-based zenith-sky UV-visible absorption spectrometers (e.g., Pommereau and Goutail, 1988; Solomon et al., 1989; McKenzie, et al., 1991; Kreher et al., 1997; Richter et al., 1999; Van Roozendael et al., 1998; Struthers et al., 2004; Hendrick et al., 2008). The main difference with the Dobson and Brewer instruments of the Global Atmospheric Watch network of the World Meteorological Organization (GAW/WMO), which are measuring ozone by direct sun and by zenith-sky spectrophotometry at low sun in the UV Huggins bands, is the use of the visible Chappuis bands, a wavelength range not applicable to ground-based direct sun or satellite nadir-viewing instruments observing at high sun. It allows twice daily $\mathrm{O}_{3}$ measurements at twilight throughout the year at all latitudes up to the polar circle, with moreover limited sensitivity to the cloud cover. In the UV-visible spectrometry technique, trace gas species amounts are retrieved by analyzing zenith-sky radiance spectra at large solar zenith angle (SZA) using the Differential Optical Absorption Spectroscopy (DOAS; Platt and Stutz, 2008) method consisting of fitting the narrow absorption features of the species with laboratory absorption cross sections without further calibration procedure. Slant column densities (SCDs), which are the direct product of the DOAS analysis, are then converted into vertical column densities (VCDs) using the so-called air mass factors (AMFs) derived by radiative transfer calculations from locally measured or climatological $\mathrm{O}_{3}$ and atmospheric air density profiles.

The NDACC network (formerly NDSC: Network for the Detection of Stratospheric Change) is formally operational since 1991 and is composed of more than 70 high-quality remote-sensing research stations for observing and understanding the composition and structure of the stratosphere and troposphere. Within NDACC, the UV-visible network consists of more than 35 certified UV-visible spectrometers operating from pole to pole and providing time-series of $\mathrm{O}_{3}$ and $\mathrm{NO}_{2}$ total columns made publicly available on the network web site (http://www.ndacc.org). These data have been compared to Dobson and Brewer ground-based (Kyrö, 1993; Høiskar et al., 1997; Van Roozendael et al., 1998), and satellite measurements (e.g., Lambert et al., 1999), showing significant biases as well as systematic seasonal variations in the difference attributed to cross-sections and SZA dependencies in the UV measurements, and the lack of seasonal variation in the AMFs used to derive total ozone columns from twilight zenith-sky UV-vis SCDs. Data evaluation and quality assessment procedures, which are under the responsibility of the NDACC UV-visible Working Group (WG), are essential for ensuring the quality of these data sets on a long-term basis. Within this objective, the NDACC UV-visible WG is organizing regularly field instruments and algorithms intercomparison campaigns. The first took place in Lauder $\left(45^{\circ} \mathrm{S}\right.$, $170^{\circ} \mathrm{E}$ ) in New Zealand in 1992 (Hofmann et al., 1995), and was followed by several others in Camborne $\left(50^{\circ} \mathrm{N}, 5^{\circ} \mathrm{W}\right)$ in the UK in 1994 (Vaughan et al., 1997), at the Observatoire de Haute Provence (OHP; $44^{\circ} \mathrm{N}, 6^{\circ} \mathrm{E}$ ) in France in 1996 (Roscoe et al., 1999), in Andøya $\left(69^{\circ} \mathrm{N}, 16^{\circ} \mathrm{E}\right)$ in Norway in 2003 (Vandaele et al., 2005), and more recently in Cabauw $\left(52^{\circ} \mathrm{N}, 5^{\circ} \mathrm{E}\right)$ in the Netherlands in 2009 , as part of the CINDI campaign (Roscoe et al., 2010). Despite this effort of cross evaluations, it has been recognized that the $\mathrm{O}_{3}$ data sets still suffer from residual inconsistencies mainly due to (1) differences in the DOAS settings, in particular the ozone absorption cross sections used for the various instruments and (2) a lack of homogeneity in the AMFs applied to $\mathrm{O}_{3}$ slant columns for their conversion into vertical columns. Recently, the NDACC UV-visible WG has formulated recommendations and provided tools and input data sets aiming at improving the homogeneity of the UV-visible total ozone measurements delivered to the NDACC database. Here we report on these recommendations and illustrate the benefit of their use by a comparison between total ozone measurements made by a selection of SAOZ (Système d'Analyse par Observation Zénithale; Pommereau and Goutail, 1988) spectrometers belonging to the NDACC UV-visible network and collocated observations performed by other instruments.

The present paper is divided into 4 parts. Section 2 provides a description of the NDACC UV-visible WG recommendations for DOAS settings and $\mathrm{O}_{3}$ AMF calculations. Section 3 is devoted to the analysis of the error budget on the retrieved $\mathrm{O}_{3}$ vertical columns. An illustration of the application of the recommended settings to the NDACC/SAOZ network is then given in Sect. 4, including a comparison between $\mathrm{SAOZ}$ total $\mathrm{O}_{3}$ columns at different stations from the Arctic to the Antarctic and collocated satellite, Dobson, and Brewer observations. Concluding remarks are given in Sect. 5.

\section{Total ozone retrieval}

\subsection{Description}

Ozone is retrieved in the visible Chappuis bands in a wavelength range of about $100 \mathrm{~nm}$ wide centered around $500 \mathrm{~nm}$, taking into account the spectral signature of $\mathrm{O}_{3}, \mathrm{NO}_{2}, \mathrm{H}_{2} \mathrm{O}$, 
$\mathrm{O}_{4}$, and the filling-in of the solar Fraunhofer bands by the Ring effect (Grainger and Ring, 1962).

The $\mathrm{O}_{3}$ differential slant column density (DSCD), which is the amount of $\mathrm{O}_{3}$ present in the optical path that the light follows to the instrument minus that from a reference measurement, is the direct product of the DOAS analysis. It is converted into a vertical column amount using the following equation:

$\operatorname{VCD}(\theta)=\frac{\operatorname{DSCD}(\theta)+\mathrm{RCD}}{\operatorname{AMF}(\theta)}$

where $\operatorname{VCD}(\theta)$ is the vertical column density at SZA $\theta$, $\operatorname{DSCD}(\theta)$ the differential slant column density at SZA $\theta$, RCD the residual ozone amount in the reference measurement (a fixed spectrum recorded at high sun around local noon), and $\operatorname{AMF}(\theta)$ the airmass factor at SZA $\theta$.

RCD is derived using the so-called Langley plot method, which consists in rearranging Eq. (1) and plotting $\operatorname{DSCD}(\theta)$ as a function of $\operatorname{AMF}(\theta)$, the intercept at $\mathrm{AMF}=0$ giving RCD (Roscoe et al., 1994; Vaughan et al., 1997). Sunrise and sunset $\mathrm{O}_{3}$ column data provided to the NDACC database are derived by averaging vertical columns estimated with Eq. 1 over a limited SZA range around $90^{\circ}$ SZA (generally $86-$ $91^{\circ}$ SZA). The AMF, also called geometrical enhancement, is defined as the ratio between the slant and vertical column densities (Solomon et al., 1987). It is computed at a single wavelength chosen around $500 \mathrm{~nm}$ with a radiative transfer model (RTM) initialized with $\mathrm{O}_{3}$, pressure, temperature, and aerosol extinction profiles representative, as much as possible, of the atmosphere at the location of the station.

\subsection{Sensitivity study}

In this Section, we examine the sensitivity of the groundbased UV-visible twilight measurements to the vertical distribution of ozone in the troposphere and stratosphere through the use of the averaging kernels. These parameters are particularly appropriate for that purpose since they describe the sensitivity of the slant column, i.e. the depth of the absorption features in the measured spectra, to variations of trace gas concentration at a given altitude. According to Eskes and Boersma (2003), the averaging kernel of layer $l$ can be approximated by the ratio of the box-airmass factor of layer $l\left(\mathrm{AMF}_{l}\right)$ and the total air-mass factor $\left(\mathrm{AMF}_{\text {tot }}\right)$ calculated from the ozone profile:

$A_{l}=\mathrm{AMF}_{l} / \mathrm{AMF}_{\text {tot }}$

A typical example of such averaging kernels corresponding to $90^{\circ} \mathrm{SZA}$ at $45^{\circ} \mathrm{N}$ in June is shown in Fig. 1. It has been computed using the UVSPEC/DISORT RTM (Mayer and Kylling, 2005) initialized with $\mathrm{O}_{3}$, pressure, and temperature profiles from the TOMS TV8 climatology (McPeters et al., 2007). Since the mean scattering layer is located around $14 \mathrm{~km}$ altitude, the sensitivity of zenith sky twilight measurements to tropospheric ozone is limited, with averaging kernel value smaller than 0.5 below $8 \mathrm{~km}$, and increases in the

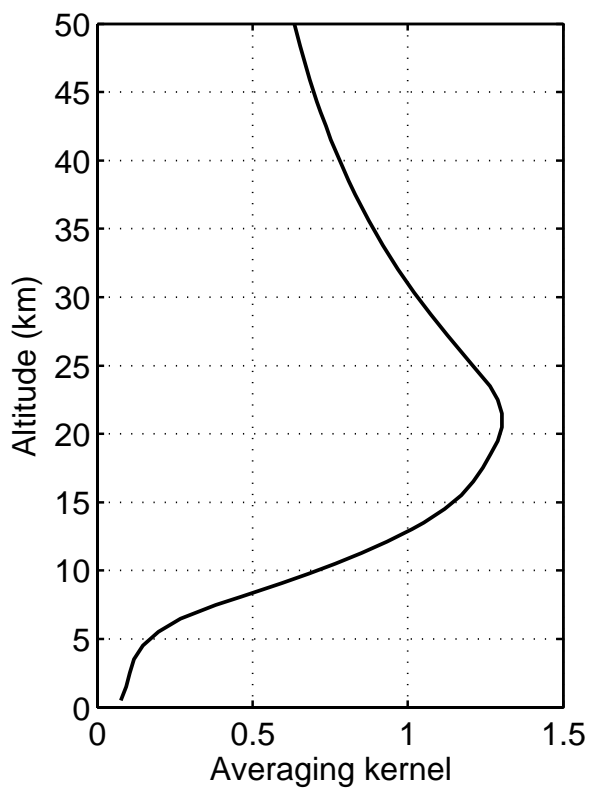

Fig. 1. Column averaging kernel (left plot) computed for $90^{\circ} \mathrm{SZA}$ in zenith-sky geometry using the ozone and temperature profiles corresponding to $45^{\circ} \mathrm{N} / 325 \mathrm{DU}$ in June extracted from the TOMS V8 zonal mean climatology. The wavelength is fixed to $500 \mathrm{~nm}$.

stratosphere where averaging kernel value is larger than 1 between $14-30 \mathrm{~km}$ altitude. So the twilight zenith-sky UVvis total column ozone measurements are strongly weighted by the contribution of the stratosphere and therefore show very limited sensitivity to the uncertainties on parameters affecting tropospheric ozone like e.g. Mie scattering in a cloud layer. However, these measurements are sensitive to the tropospheric ozone column used for the AMF calculation which acts as a ghost column in the total column retrieval.

\subsection{Recommended NDACC settings}

So far, NDACC UV-visible groups commonly used their own DOAS settings and $\mathrm{O}_{3}$ AMFs calculated with different RTMs and sets of ozone, pressure and temperature profiles, with or without latitudinal and seasonal variations. Differences between AMFs are causing the largest discrepancies between the NDACC $\mathrm{O}_{3}$ data sets. The objective of the recommendations formulated by the NDACC UV-visible WG is thus to reduce these discrepancies through the use of standardized DOAS settings and $\mathrm{O}_{3}$ AMF look-up tables (LUTs) that account for the latitudinal and seasonal dependencies of the $\mathrm{O}_{3}$ vertical profile.

\subsubsection{DOAS settings}

The NDACC recommendations for the ozone DOAS retrieval are summarized in Table 1. Optimizing retrieval settings for total ozone in the visible Chappuis bands requires 
Table 1. Settings recommended for the UV-visible retrieval of $\mathrm{O}_{3}$ vertical columns.

\begin{tabular}{ll}
\hline Parameter & Recommendation \\
\hline Fitting interval & $450-550 \mathrm{~nm}$ \\
Wavelength calibration & Calibration based on reference solar atlas (Kurucz, 1984) \\
Cross-sections & \\
$\mathrm{O}_{3}$ & Bogumil et al. (2003), 223 ${ }^{\circ} \mathrm{K}$ \\
$\mathrm{NO}_{2}$ & Vandaele et al. (1997), 220 $\mathrm{K}$ \\
$\mathrm{H}_{2} \mathrm{O}$ & Hitran 2004 (Rothman et al., 2005) \\
$\mathrm{O}_{4}$ & Hermans (http://spectrolab.aeronomie.be/o2.htm) \\
$\mathrm{Ring}$ effect & Chance and Spurr (1997) \\
$\mathrm{Molecular}$ and aerosol scattering & Polynomial of order 3, or equivalent non-polynomial high-pass filtering \\
AMF calculation & BIRA-IASB O 3 AMF LUTs \\
Determination of residual amount in reference spectrum & Langley plot (Vaughan et al., 1997) \\
SZA range for twilight averaging of vertical columns & 86-91 \\
\hline
\end{tabular}

consideration on how the differential ozone signal can be extracted with maximum sensitivity, while minimizing spectral interferences with other absorbers, which are, in the present spectral range, water vapor and the collision pair $\mathrm{O}_{2}-\mathrm{O}_{2}$. From sensitivity studies conducted on simulated spectra and actual measurements, it was found that ozone fitting uncertainties are minimized using the $450-550 \mathrm{~nm}$ spectral interval, which was therefore selected as a baseline for ozone retrieval in the Chappuis bands. As an illustration, a typical example of fit result is displayed in Fig. 2. This was obtained in ScoresbySund, Greenland, on 16 July 2008 , at $88.0^{\circ}$ SZA and 00:59 UT time. The retrieved contributions from $\mathrm{O}_{3}$, $\mathrm{NO}_{2}, \mathrm{H}_{2} \mathrm{O}, \mathrm{O}_{4}$ and Ring effect are shown separately. Given the importance of wavelength registration for DOAS evaluations in general, the recommendation is that measured spectra are aligned with the highest accuracy. This can be obtained by correlating measured spectra with a reference solar spectrum such as those of Kurucz (1984) or Chance and Spurr (1997), using least-squares techniques as implemented e.g. in the Windoas software suite (Fayt and Van Roozendael, 2009) or in the SAOZ analysis algorithm (Pommereau and Piquard, 1994). Different data sets of ozone absorption cross-sections are available from the literature. Comparison studies (e.g. Orphal, 2003) showed that differences of up to 4 percent can occur in the region of the Chappuis bands, and even more in the Huggins bands. Therefore the recommendation is the use of a common ozone cross-sections data set to avoid systematic differences. From test evaluations, that of Bogumil et al. (2003) is recommended since it gives the smallest variance in the residuals as well as good consistency with the ozone retrieval in the UV Huggins bands. Recommendations for laboratory cross section data sets of other species interfering in the $450-550 \mathrm{~nm}$ range are provided in Table 1 . Vandaele et al. (1997) at $220^{\circ} \mathrm{K}$ is generally used for stratospheric $\mathrm{NO}_{2}$ retrievals and therefore adequate for $\mathrm{NO}_{2}$ removal in the $\mathrm{O}_{3}$ fitting range. For correction of

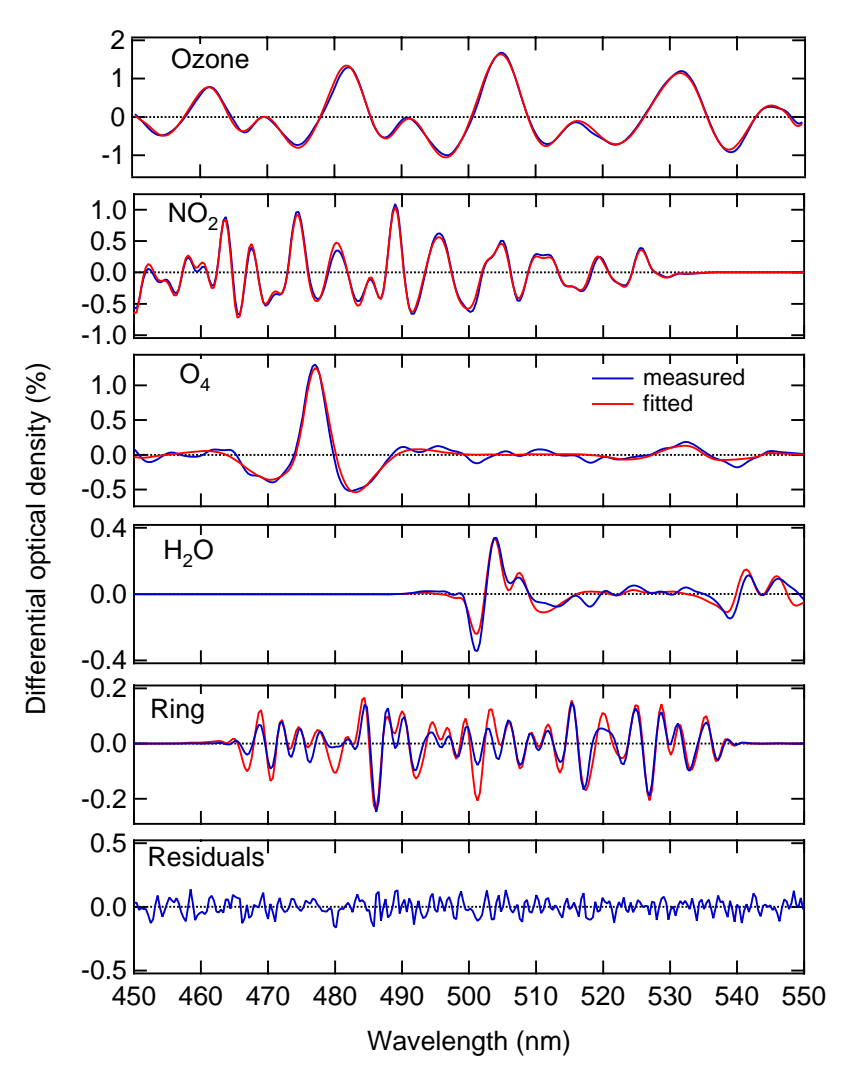

Fig. 2. Typical example of ozone differential slant column fit result, obtained in ScoresbySund, Greenland, on 16 July 2008. The spectrum was recorded at 00:59 UT and $88.0^{\circ}$ SZA. The successive subplots display the respective contributions from $\mathrm{O}_{3}, \mathrm{NO}_{2}$, $\mathrm{O}_{4}, \mathrm{H}_{2} \mathrm{O}$ and the Ring to the measured and simulated differential optical density. Fitting residuals are shown at the bottom.

the Ring effect filling-in solar Fraunhofer lines, the approach published in Chance and Spurr (1997) is recommended. One should note that the ozone differential absorption features 
Table 2. Parameters used to initialize the UVSPEC/DISORT RTM for the calculation of the $\mathrm{O}_{3}$ AMF LUTs.

\begin{tabular}{|c|c|}
\hline Parameter & Value \\
\hline $\mathrm{O}_{3}$ profile & $\begin{array}{l}\text { TOMS version } 8 \text { climatology (TV8): } \\
\text { - Latitude: } 85^{\circ} \mathrm{S} \text { to } 85^{\circ} \mathrm{N} \text { step } 10^{\circ} \\
\text { - Month: } 1 \text { (Jan) to } 12 \text { (Dec) step } 1 \\
\text { - Ozone column: } 125 \text { to } 575 \text { DU step } 50 \mathrm{DU}\end{array}$ \\
\hline Temperature and pressure profiles & TOMS version 8 climatology (TV8) \\
\hline Altitude grid & 0 to $120 \mathrm{~km}$ step $1 \mathrm{~km}$ \\
\hline Wavelength & 440 to $580 \mathrm{~nm}$ step $35 \mathrm{~nm}$ \\
\hline Surface albedo & 0 and 1 \\
\hline Altitude output & 0 and $4 \mathrm{~km}$ \\
\hline SZA & $30,50,70,80,82.5,85,86,87,88,89,90,91$, and $92^{\circ}$ \\
\hline
\end{tabular}

are broad enough in the Chappuis bands to ensure that their filling-in by the Ring effect is quite small. However, due to its impact on the Fraunhofer lines, the Ring effect cannot be neglected. Finally, as already mentioned, the NDACC recommendation for twilight reporting is to average all retrieved ozone vertical columns between $86^{\circ}$ and $91^{\circ} \mathrm{SZA}$. This range minimizes errors due to slant column fitting and AMF calculation (see Sect. 3) and provides stratospheric ozone measurements with limited sensitivity to tropospheric ozone and clouds.

\subsection{2 $\mathrm{O}_{3} \mathrm{AMFs}$}

\section{Description}

Look-up tables (LUTs) of $\mathrm{O}_{3}$ AMFs have been developed at the Belgian Institute for Space Aeronomy (BIRA-IASB) in support of the NDACC UV-visible WG. These are based on the TOMS version 8 (TV8) ozone and temperature profile climatology. TV8 is similar to the climatology of McPeters et al. (2007), i.e. a monthly mean climatology for $10^{\circ}$ latitude bands between $90^{\circ} \mathrm{S}$ and $90^{\circ} \mathrm{N}$ and covering altitudes from 0 to $60 \mathrm{~km}$, with in addition a total $\mathrm{O}_{3}$ column dependence (225-325 Dobson Unit (DU) in the tropics, 225-575 DU at mid-latitudes, and 125-575 DU at high-latitudes, with for all cases a 50 DU step). A total ozone column classification allows reproducing the short-term variations of the ozone profile. TV8 was built by combining profile data from SAGE II (Stratospheric Aerosol and Gas Experiment II), MLS (Microwave Limb Sounder), and ozonesondes. This climatology has been widely utilized for the retrieval of global total ozone fields from recent US and European UV-visible nadir satellite sounders (e.g., Bhartia et al., 2004; Coldewey-Egbers et al., 2005; Eskes et al., 2005; Weber et al., 2005; Van Roozendael et al., 2006; Lamsal et al., 2007).

The $\mathrm{O}_{3}$ AMF LUTs are calculated for the eighteen TV8 zonal bands using the UVSPEC/DISORT RTM which is based on the Discrete Ordinate Method and includes a treatment of the multiple scattering in a pseudo-spherical geome- try. The model has been validated through several intercomparison exercises (e.g., Hendrick et al., 2006; Wagner et al., 2007). Parameter values used to initialize UVSPEC/DISORT for the calculation of the AMF LUTs are summarized in Table 2. Since the TV8 climatology is limited to the 0 $60 \mathrm{~km}$ altitude range, the $\mathrm{O}_{3}$, temperature, and pressure profiles are complemented above $60 \mathrm{~km}$ by the AFGL Standard Atmosphere for matching with the altitude grid chosen in UVSPEC/DISORT for the present study, which is $0-90 \mathrm{~km}$. The surface albedo and altitude output values (varying from 0 to 1 and 0 to $4 \mathrm{~km}$, respectively) allow covering all NDACC stations. Regarding the aerosol settings, an extinction profile corresponding to a background aerosol loading has been selected from the aerosol model of Shettle (1989) included in UVSPEC/DISORT. The present $\mathrm{O}_{3}$ AMF LUTs are thus not suitable in case of large volcanic eruption such as that of the Mount Pinatubo in 1991.

The calculated LUTs depend on the following set of parameters: latitude, day of year, $\mathrm{O}_{3}$ column, wavelength, SZA, surface albedo, and altitude. An interpolation routine has been designed for extracting appropriately parameterized $\mathrm{O}_{3}$ AMFs for the various NDACC stations. A global monthly mean climatology of the surface albedo derived from satellite data at $494 \mathrm{~nm}$ (Koelemeijer et al., 2003) is coupled to the interpolation routine, so the latter can be initialized with realistic albedo values in a transparent way. The interpolation routine, $\mathrm{O}_{3}$ AMF LUTs, albedo climatology as well as DOAS settings are publicly available at http://uv-vis.aeronomie.be/groundbased.

\section{Comparison to $\mathrm{SAOZ} \mathrm{O}_{3} \mathrm{AMFs}$}

So far, SAOZ retrievals made use of constant AMFs calculated at the latitude of each station from mean SAGE II, POAM and SAOZ balloon profiles in the summer (Sarkissian et al., 1995). For illustrating the impact of using the new $\mathrm{O}_{3}$ AMF LUTs, time-series of AMFs have been extracted from the LUTs for one year of data at four SAOZ stations of the NDACC network: Sodankyla $\left(67^{\circ} \mathrm{N}, 27^{\circ} \mathrm{E}\right)$, Observatoire 
de Haute Provence $\left(44^{\circ} \mathrm{N}, 6^{\circ} \mathrm{E}\right)$, Bauru $\left(22^{\circ} \mathrm{S}, 46^{\circ} \mathrm{W}\right)$, and Dumont d'Urville $\left(67^{\circ} \mathrm{S}, 140^{\circ} \mathrm{E}\right)$. The wavelength is fixed to $500 \mathrm{~nm}$, the surface albedo to 0.2 , and the station altitude to $0 \mathrm{~km}$. The $\mathrm{O}_{3}$ column values needed to properly extract AMFs from the LUTs have been taken from the data files available on the NDACC database for year 2005. Comparisons between LUT and SAOZ annual mean AMFs are shown in Fig. 3. As expected, the difference displays a strong seasonality. At mid- and high-latitudes, the largest difference is seen in the winter with LUT AMFs larger than that of SAOZ by up to $8 \%$. In the summer, the difference is within the $0-2 \%$ range in Sodankyla and OHP. At Dumont d'Urville (polar circle in the Southern Hemisphere), the LUT AMFs are larger than that of SAOZ by $11 \%$ in the summer and $5 \%$ in the winter. In the tropics, they are systematically larger by $2 \%$ on average with no seasonality in the difference, however the differences are noisier compared to other latitudes. This larger noise can be explained by the variability of the ozone profile shape above the Tropical Tropopause Layer (TTL) at altitudes from 20 to $30 \mathrm{~km}$ where the measurement sensitivity is largest (see Fig. 1), which therefore means a more significant impact on the AMF. As an example, the AMF in January in Bauru varies from 16.5 to 17.0, that is by $3 \%$, when using ozone profiles extracted from the TV8 climatology for typical total column values of 244 and 278 DU. Thus, small changes in total ozone of about $50 \mathrm{DU}$ on a few days time scale, as frequently observed in Bauru, result in significant changes in the AMF. For comparison, the AMF at $65^{\circ} \mathrm{N}$ in April corresponding to total column values of 332 and 417 DU (typical values around the mean total ozone column value at Sodankyla) is varying from 16.8 to 16.9 , respectively, which corresponds to a change of $0.5 \%$ only. This explains the smaller short-term variability in the AMF at mid- and high-latitudes.

\section{Error budget}

The error budget of the measurements is obtained by considering error sources affecting the determination of the differential slant column densities (DSCD), the residual amount in the reference spectrum (RCD), and the air mass factor (AMF).

\subsection{DOAS analysis}

Errors associated to the least-squares fit are due to detector noise, instrumental imperfections (small wavelength scale and resolution changes, etaloning and non-linearities of the detector, stray-light, polarisation effects, ...) as well as errors or unknowns in the signal modelling (Ring effect, unknown absorbers, wavelength dependence of the AMF, etc). To some extent, such errors are pseudo-random in nature and, as such, can be estimated statistically from the least-squares fit procedure. Fitting errors derived from the least-squares
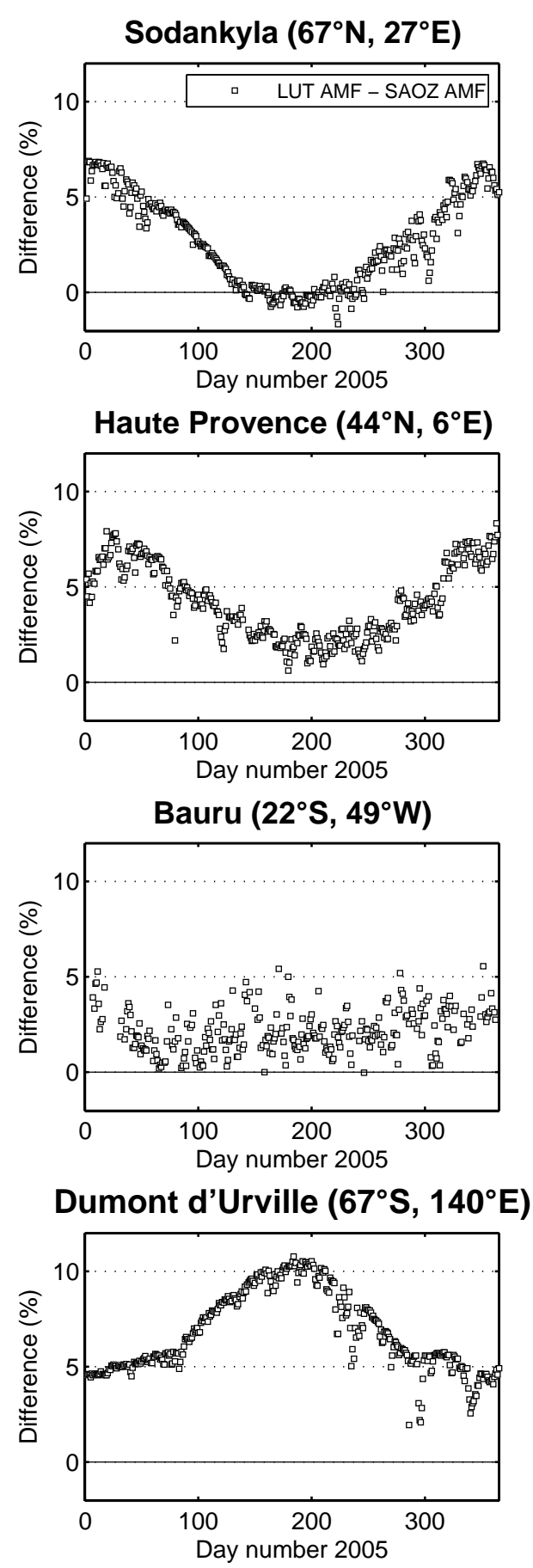

Fig. 3. Relative differences between LUT and $\mathrm{SAOZ} \mathrm{O}_{3} \mathrm{AMFs}$ at $90^{\circ} \mathrm{SZA}$ for the year 2005 at Sodankyla $\left(67^{\circ} \mathrm{N}, 27^{\circ} \mathrm{E}\right)$, Haute Provence $\left(44^{\circ} \mathrm{N}, 6^{\circ} \mathrm{E}\right)$, Bauru $\left(22^{\circ} \mathrm{S}, 49^{\circ} \mathrm{W}\right)$, and Dumont d'Urville $\left(67^{\circ} \mathrm{S}, 140^{\circ} \mathrm{E}\right)$. The SAOZ tropical, high- and midlatitude $\mathrm{O}_{3}$ AMF values at $90^{\circ} \mathrm{SZA}$ are $16.20,16.22$, and 16.52 , respectively. 
Table 3. List of $\mathrm{O}_{3}$ profile measurements used for testing the validity of the TV8 climatology for $\mathrm{O}_{3}$ AMF calculations. The last column is the mean relative difference (and the corresponding $1 \sigma$ standard deviation) between $\mathrm{O}_{3} \mathrm{AMF}_{86-91}{ }^{\circ} \mathrm{SZA}$ extracted from the LUTs and calculated using the $\mathrm{O}_{3}$ profiles measured at the different NDACC stations (see Fig. 4).

\begin{tabular}{llrrr}
\hline Station & Instrument & Time period & $\begin{array}{r}\text { Number } \\
\text { of profiles }\end{array}$ & $\begin{array}{r}\text { Mean } \mathrm{O}_{3} \mathrm{AMF}_{86-91{ }^{\circ} \mathrm{SZA}} \\
\text { difference }(\%)\end{array}$ \\
\hline Ny-Ålesund $\left(79^{\circ} \mathrm{N}, 12^{\circ} \mathrm{E}\right)$ & $\mathrm{O}_{3}$ sonde & $01 / 2004-12 / 2006$ & 218 & $-0.3 \pm 1.3$ \\
Andoya $\left(69^{\circ} \mathrm{N}, 16^{\circ} \mathrm{E}\right)$ & Lidar & $01 / 2004-12 / 2006$ & 122 & $-1.7 \pm 1.1$ \\
$\mathrm{OHP}\left(44^{\circ} \mathrm{N}, 6^{\circ} \mathrm{E}\right)$ & $\mathrm{O}_{3}$ sonde & $01 / 2003-12 / 2006$ & 113 & $-1.1 \pm 1.3$ \\
& Lidar & $01 / 2004-12 / 2006$ & 377 & $-1.2 \pm 0.7$ \\
Izaña $\left(28^{\circ} \mathrm{N}, 16^{\circ} \mathrm{W}\right)$ & $\mathrm{O}_{3}$ sonde & $01 / 2004-12 / 2006$ & 218 & $0.5 \pm 1.7$ \\
Reunion Island $\left(21^{\circ} \mathrm{S}, 55^{\circ} \mathrm{E}\right)$ & $\mathrm{O}_{3}$ sonde & $01 / 2000-12 / 2002$ & 59 & $-0.8 \pm 1.8$ \\
Lauder $\left(45^{\circ} \mathrm{S}, 170^{\circ} \mathrm{E}\right)$ & $\mathrm{O}_{3}$ sonde & $01 / 2004-12 / 2006$ & 139 & $-1.3 \pm 0.9$ \\
& Lidar & $01 / 2004-12 / 2006$ & 208 & $-1.4 \pm 0.7$ \\
Dumont d'Urville $\left(67^{\circ} \mathrm{S}, 140^{\circ} \mathrm{E}\right)$ & $\mathrm{O}_{3}$ sonde & $07 / 2002-12 / 2006$ & 116 & $0.4 \pm 2.0$ \\
\hline
\end{tabular}

analysis typically give small uncertainties of the order $5 \mathrm{DU}$ for $\mathrm{O}_{3}$ DSCDs. However, results from intercomparisons exercises (e.g. Van Roozendael et al., 1998; Vandaele et al., 2005; Roscoe et al., 2010) show that state-of-the-art instruments hardly agree to better than a few percents, even using standardised analysis procedures, which indicates that the actual accuracy on the DSCDs is limited by uncontrolled instrumental and/or analysis factors. Based on experience and results from intercomparison campaigns, we quote an uncertainty of the order of $3 \%$ for the $\mathrm{O}_{3}$ DSCD. This error adds up to systematic uncertainties on ozone absorption cross sections in the Chappuis bands and on their (very small) temperature dependence which is of the order of $3 \%$ in our spectral range (Orphal, 2003).

The accuracy on the determination of residual amount in the reference spectrum (RCD) is limited by the method used to derive the vertical column at the time of the reference spectrum acquisition. Here we use a Langley-plot approach. The contribution from this error source to the total error budget is small, of the order of $1 \%$.

\subsection{AMF LUTs}

A potential source of uncertainty in our $\mathrm{O}_{3}$ AMF calculation is related to the use of the TV8 $\mathrm{O}_{3}$ profile climatology, originally designed for nadir backscatter measurements from space. In order to test the validity of this climatology in the present context, $\mathrm{O}_{3}$ AMFs extracted from the LUTs have been compared to calculations performed using $\mathrm{O}_{3}$ profiles measured with ozonesondes and/or lidar observations at several NDACC stations representative of a wide range of conditions (tropics, mid- and high-latitudes). The stations and instruments used are listed in Table 3 and the data have been downloaded from the NDACC database (http://www.ndacc.org). In case of lidar, profiles have been complemented below their lower altitude limit by the TV8 climatology. Pressure and temperature profiles are taken
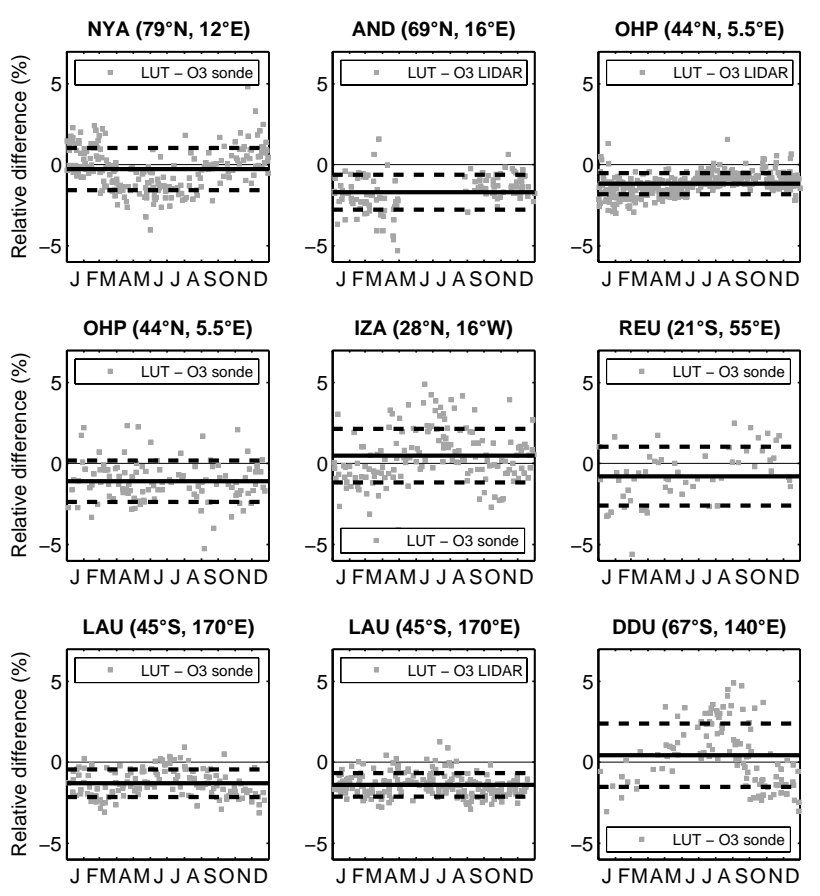

Fig. 4. Relative difference between $\mathrm{O}_{3} \mathrm{AMF}_{86-91^{\circ} S Z A}$ extracted from the LUTs and calculated using the $\mathrm{O}_{3}$ profiles measured at the following NDACC stations: Ny-Ålesund (NYA), Andoya (AND), Observatoire de Haute Provence (OHP), Izaña (IZA), Reunion Island (REU), Lauder (LAU), and Dumont d'Urville (DDU). Filled grey squares: daily relative differences, black solid lines: yearly mean relative difference, and black dashed lines: $1 \sigma$ standard deviation (see Table 3 for corresponding values).

from the AFGL Standard Atmosphere when not available in the lidar data files. The aerosol extinction profile is the same as the one used for the calculation of the LUTs (see first subsection of Sect. 2.3.2). Other settings required for initializing the UVSPEC/DISORT RTM are identical to those fixed 
for the extraction of the $\mathrm{O}_{3}$ AMFs from the LUTs (wavelength: $500 \mathrm{~nm}$, surface albedo: 0.2 , station altitude: $0 \mathrm{~km}$ ). $\mathrm{O}_{3}$ AMFs are calculated for between 86 and $91^{\circ}$ SZA by $1^{\circ}$ SZA step using the measured $\mathrm{O}_{3}$ profiles and compared to those extracted from the LUTs for the same SZA range. Figure 4 depicts the seasonal variation of the difference between LUT AMFs and those calculated from sonde or lidar measurements between 86 and $91^{\circ} \mathrm{SZA}$ (called hereafter

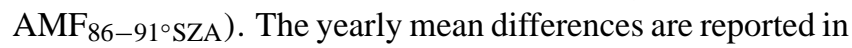
Table 3. On average, the largest mean relative differences between $\mathrm{O}_{3} \mathrm{AMF}_{86-91^{\circ} \text { SZA }}$ extracted from the LUTs and those calculated with the measured $\mathrm{O}_{3}$ profiles are obtained with lidar. However, these relative differences show smaller seasonality and less noise than those derived from the sondes, especially at high latitude at Ny-Ålesund and Dumont D'Urville and in the tropics at Izaña and Reunion Island. These significant residual seasonalities could be related to the zonal dependence of the tropospheric ozone seasonality not implemented in the TV8 climatology and displaying a maximum in the summer at the Northern Hemisphere and in spring at the southern tropics (see Figs. 15 and 16), and to systematic errors in the TV8 in the winter at high latitude at low sun where SAGE II data are no more available. The larger noise with the sondes might come from their precision limited to $5 \%$. Nevertheless, since the mean relative difference for the nine comparison cases considered here is $-1 \pm 1.3 \%$, these results show that the TV8 climatology reproduces well on average the mean $\mathrm{O}_{3}$ profiles latitudinal and seasonal variations, so that sufficiently accurate $\mathrm{O}_{3}$ AMFs can be calculated.

The choice of the aerosol extinction profile is also a source of uncertainty in our $\mathrm{O}_{3}$ AMF calculations. The UVSPEC/DISORT RTM includes the aerosol climatology of Shettle (1989), which consists of a set of extinction profiles corresponding to different volcanic conditions (background, moderate, high, and extreme). For the present study, we have selected the aerosol extinction profile corresponding to background conditions, with a surface visibility of $40 \mathrm{~km}$ (called hereafter the standard settings). In order to give an upper limit of the uncertainty related to the choice of the aerosol settings, $\mathrm{O}_{3}$ AMFs corresponding to moderate volcanic conditions have been calculated. The $\mathrm{O}_{3}$ profiles are selected from the TV8 climatology for the following conditions: $25^{\circ} \mathrm{N} / 275 \mathrm{DU}, 45^{\circ} \mathrm{N} / 325 \mathrm{DU}$, and $65^{\circ} \mathrm{N} / 325 \mathrm{DU}$ in June. Figure 5 (upper panels) shows the comparison of $\mathrm{O}_{3}$ AMFs calculated with standard and moderate volcanic aerosol settings. The relative difference is smaller than $2 \%$ except at SZA larger than $87^{\circ}$ in the tropics where the $\mathrm{O}_{3}$ AMFs corresponding to moderate volcanic conditions are larger than the standard ones by up to $4 \%$. However, the mean relative difference in the $86-91^{\circ} \mathrm{SZA}$ range for the three selected $\mathrm{O}_{3}$ profiles is $0.6 \%$. Similar comparison results are obtained for winter $\mathrm{O}_{3}$ profiles.

Clouds are not accounted for in our $\mathrm{O}_{3}$ AMF calculations but their impact has been investigated using the water clouds
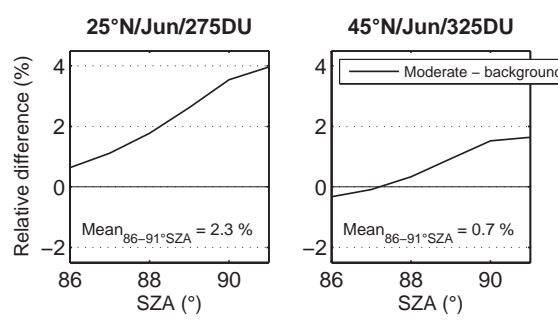

$65^{\circ} \mathrm{N} / \mathrm{Jun} / 325 \mathrm{DU}$
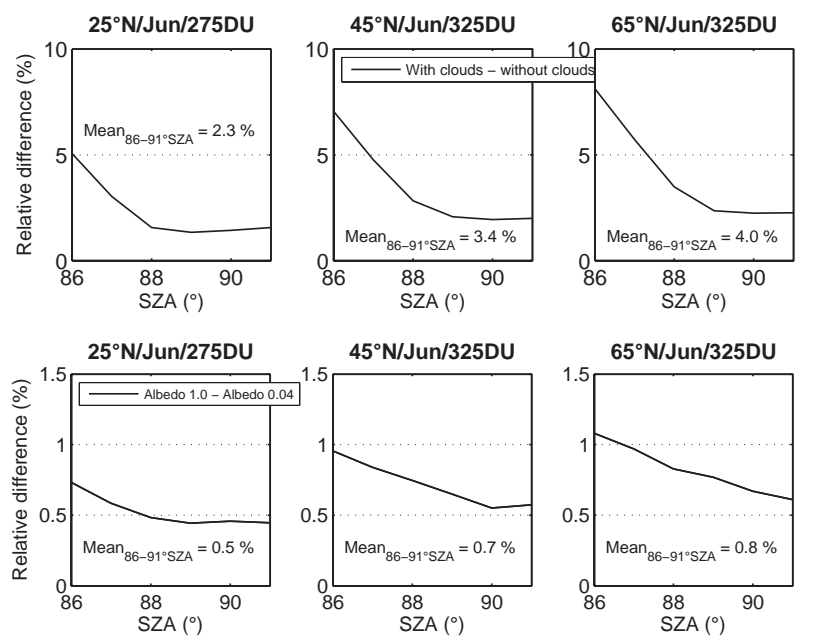

$65^{\circ} \mathrm{N} / \mathrm{Jun} / 325 \mathrm{DU}$
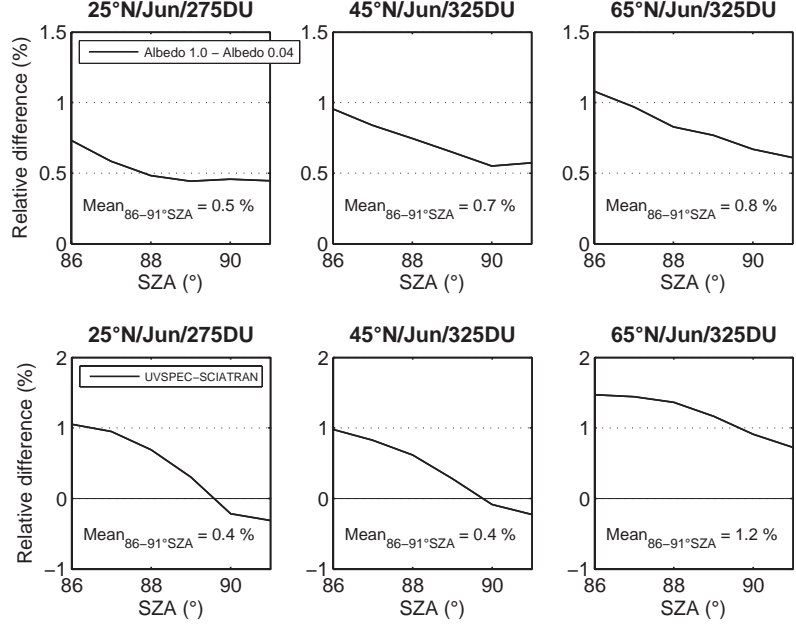

Fig. 5. From top to bottom, comparison of $\mathrm{O}_{3}$ AMFs calculated using standard and moderate volcanic aerosol settings, with and without the presence of clouds, with surface albedo fixed to 1.0 and 0.04 , and with UVSPEC and SCIATRAN RTMs. The mean relative difference calculated in the $86-91^{\circ}$ SZA range appears on each plot. In case of the aerosols sensitivity test, the overall mean relative difference over the $86-91^{\circ} \mathrm{SZA}$ range is of $0.6 \%$ while it reaches $3.3 \%, 0.7 \%$, and $0.7 \%$ for the test on clouds, surface albedo, and RTMs, respectively. The $\mathrm{O}_{3}$ profiles selected from the TV8 climatology for the present comparison correspond to the following conditions: $25^{\circ} \mathrm{N} / 275 \mathrm{DU}$ (left plots), $45^{\circ} \mathrm{N} / 325 \mathrm{DU}$ (middle plots), and $65^{\circ} \mathrm{N} / 325 \mathrm{DU}$ (right plots) in June. The wavelength, surface albedo, and altitude are fixed to $500 \mathrm{~nm}$ ( $541 \mathrm{~nm}$ for test on RTMs), 0.2 , and $0 \mathrm{~km}$, respectively. $\mathrm{O}_{3}$ AMF are mostly impacted by the presence of clouds (stratus layer in the present case), reducing the AMF by $3.4 \%$ on average in the $86-91^{\circ}$ SZA range at mid-latitude.

model included in UVSPEC/DISORT. The way to initialize this model is to specify the vertical profile of liquid water content and effective droplet radius. The microphysical properties of water clouds are then converted to optical properties according to the Hu and Stamnes (1993) parameterization. $\mathrm{O}_{3}$ AMFs are calculated for cloudy and non-cloudy 
conditions for the same TV8 climatology $\mathrm{O}_{3}$ profiles as above $\left(25^{\circ} \mathrm{N} / 275 \mathrm{DU}, 45^{\circ} \mathrm{N} / 325 \mathrm{DU}\right.$, and $65^{\circ} \mathrm{N} / 325 \mathrm{DU}$ in June). For cloudy conditions, the cloud model parameters values are fixed as follows: water content: $0.3 \mathrm{~g} \mathrm{~m}^{-3}$, effective droplet radius: $5 \mu \mathrm{m}$, cloud layer thickness and altitude: $1 \mathrm{~km}$ between 1 and $2 \mathrm{~km}$. Since these parameters values correspond to a rather large stratus cloud (Shettle, 1989), the present sensitivity test gives an upper limit of the impact of clouds on $\mathrm{O}_{3}$ AMFs. A comparison of $\mathrm{O}_{3}$ AMFs calculated for cloudy and non-cloudy conditions is presented in Fig. 5 (2nd line panel). Cloudy AMFs are systematically larger than non-cloudy AMFs by about $5-8 \%$ at $86^{\circ} \mathrm{SZA}$ and $2 \%$ at $91^{\circ} \mathrm{SZA}$. The mean relative difference in the $86-$ $91^{\circ} \mathrm{SZA}$ range for the three selected $\mathrm{O}_{3}$ profiles is of $3.3 \%$. Similar comparison results are obtained for winter $\mathrm{O}_{3}$ profiles. The small impact of clouds on zenith-sky ozone UVvis measurements at twilight is due to the fact that the mean scattering layer is generally located at higher altitude than that of the clouds. However, there are two exceptions: in the tropics where thunderstorms accompanied by heavy rainfall can reach $15-16 \mathrm{~km}$, and at high latitude in the winter where Polar Stratospheric Clouds (PSC) are sometimes present, disturbing the ozone measurements. These episodes are easily removed from the ground-based data series by detecting the large enhancements of $70 \%$ or more of the absorption by $\mathrm{O}_{4}$ and $\mathrm{H}_{2} \mathrm{O}$ in the tropics in the presence of thick clouds and rainfall, and by the use of a color index (ratio between irradiances at 550 and $350 \mathrm{~nm}$ ) in case of PSC (Sarkissian et al., 1991).

Another source of uncertainty we have tested is the impact of surface albedo. $\mathrm{O}_{3}$ AMFs corresponding to the same three TV8 climatology $\mathrm{O}_{3}$ profiles as above have been calculated using the UVSPEC/DISORT RTM with albedo fixed to 0.04 (ice free sea) and 1 (fresh snow, sea ice or thunderstorm anvils). Results are shown in Fig. 5 (3rd line panels). Within the $86-91^{\circ} \mathrm{SZA}$ range, the impact of surface albedo is rather low with a mean relative difference between albedo 1.0 and 0.04 cases of $0.7 \%$ for the three selected $\mathrm{O}_{3}$ profiles.

A last source of uncertainty is the impact of the RTM used for AMF calculations. Although previous studies (e.g., Hendrick et al., 2006; Wagner et al., 2007) have demonstrated that, for AMF calculation, the UVSPEC/DISORT model shows very good consistency with others RTMs, a verification exercise has been carried out to firmly assess the reliability of the present $\mathrm{O}_{3}$ AMF calculations. It consists in comparing $\mathrm{O}_{3}$ AMFs calculated using the UVSPEC/DISORT and SCIATRAN v2.2 RTMs initialized in the same way. SCIATRAN is based on the Combining Differential-Integral approach using the Picard-Iterative approximation (CDIPI) and includes a treatment of multiple scattering in full or pseudo-spherical geometry (Rozanov et al., 2005). The following settings have been used for the present exercise: pseudo-spherical geometry, TV8 $\mathrm{O}_{3}$ profile climatology, AFGL Standard Atmosphere pressure and temperature profiles, TV8 atmosphere layering (Umkehr lay-
Table 4. Error budget of zenith-sky total $\mathrm{O}_{3}$ columns measurements in the visible (\%).

\begin{tabular}{ll}
\hline Error source & Error (\%) \\
\hline (a) Random & \\
Slant column spectral fit, including interference effects & 3 \\
O $_{3}$ AMF & \\
TV8 climatology & 1.0 \\
Clouds & 3.3 \\
Aerosols & 0.6 \\
Albedo & 0.7 \\
RTM & 0.7 \\
Precision & $\mathbf{4 . 7}$ \\
\hline (b) Systematic & 3.0 \\
O3 cross sections & 2.0 \\
Residual column & $\mathbf{5 . 9}$ \\
\hline Total Accuracy & \\
\hline
\end{tabular}

ers), wavelength: $541 \mathrm{~nm}$, surface albedo: 0 , station altitude: $0 \mathrm{~km}$. Regarding the $\mathrm{O}_{3}$ profile, the following cases have been considered: polar latitude in January and June $\left(65^{\circ} \mathrm{N}\right.$ and $\mathrm{S}$ with a total column of $325 \mathrm{DU}$, mid-latitude in January and June $\left(45^{\circ} \mathrm{N}\right.$ and $\left.\mathrm{S}, 325 \mathrm{DU}\right)$, and tropics in January and June $\left(25^{\circ} \mathrm{N}\right.$ and $\left.\mathrm{S}, 275 \mathrm{DU}\right)$. The results for the Northern Hemisphere in June are shown in Fig. 5 (bottom panels). Both models are in excellent agreement with relative differences smaller than $1.5 \%$. Within the $86-91^{\circ} \mathrm{SZA}$ range, the mean relative difference is $0.7 \%$. Since similar consistency is found in January and in the Southern Hemisphere, this comparison demonstrates the reliability of the UVSPEC/DISORT RTM for $\mathrm{O}_{3}$ AMF calculation.

The overall error budget of twilight zenith-sky visible total $\mathrm{O}_{3}$ total columns measurements is summarized in Table 4 . The precision by adding quadratic random errors is $4.7 \%$ to which the largest contribution is coming from the AMF and from the error on the slant column estimated to be $3 \%$ at twilight, including the impact of unknown instrumental and systematic misfit effects. The total accuracy, important for comparison with other instruments, is $5.9 \%$.

\section{Application of the recommended settings to the NDACC/SAOZ network}

The French led SAOZ (Système d'Analyse par Observation Zénithale) network contributes significantly to the NDACC/UV-visible network with about 20 instruments covering a wide range of latitudes in both hemispheres. The SAOZ instrument is a broad-band $(300-600 \mathrm{~nm})$, medium resolution $(1 \mathrm{~nm})$ diode-array spectrometer that observes sunlight scattered at zenith sky (Pommereau and Goutail, 1988; Sarkissian et al., 1997). Absorption spectra are 
recorded hourly at SZA smaller than $85^{\circ}$ and every $5 \mathrm{~min}$ during twilight up to $94^{\circ}$ SZA. The full SAOZ data set has been reprocessed in a version V2 using the NDACC recommendations. The previous version, called V1, was using constant AMFs specific to each station (see second subsection of Sect. 2.3.2) and, regarding the DOAS settings, differs from V2 on the Ring and ozone cross-sections and the wavelength fitting window. The impact of the changes of these three parameters is discussed below.

i. Ring cross-sections. The SAOZ V1 Ring cross-sections were derived from a high-resolution differential reference spectrum. The change for Chance and Spurr (1997) procedure leads to an insignificant increase by $0.1 \% \pm 0.01 \%$ of the ozone slant column.

ii. Ozone cross-sections. SAOZ V1 was using a combination of two laboratory data sets, those of the GOME flight model (FM) at $202 \mathrm{~K}$ between 330 and $514.5 \mathrm{~nm}$ (Burrows et al., 1999) and of Brion et al. (1998) between 514.5 and $650 \mathrm{~nm}$, both normalized on Anderson and Mauersberger (1992) absolute cross-sections measured at six wavelengths thought to be the most precise available (GOME FM cross-sections multiplied by 1.029 and Brion et al. by 1.021). The change for Bogumil et al. (2003), leads to a decrease of the ozone slant column by $0.8 \% \pm 0.01 \%$.

iii. Ozone fitting window. For taking the advantage of the 8 ozone cross-sections differential features available in the Chappuis bands, the SAOZ V1 spectral range extended from $450-617 \mathrm{~nm}$, with the exception of the $580-602 \mathrm{~nm}$ ignored because of the presence of water vapor absorption bands at around $590 \mathrm{~nm}$ particularly intense in the warm tropics. The change for the 450$550 \mathrm{~nm}$ spectral range in the SAOZ V2 leads to an increase of ozone slant column by $1.6 \% \pm 0.05 \%$. However, the cause of this larger ozone is not the spectral fitting but the decrease of slant column at increasing wavelength because of the lower altitude of the mean scattering level of sunlight at twilight. After conversion into vertical column using SAOZ AMFs calculated at the center of the windows, of 16.41 at $500 \mathrm{~nm}$ instead of 16.22 at $540 \mathrm{~nm}$, the change in vertical column is only $0.2 \% \pm 0.05 \%$.

Overall, the change between V1 and V2 after applying the NDACC UV-Vis working group recommendations for DOAS settings is a decrease of ozone vertical column at twilight by $0.5 \%$, which is not significant.

\subsection{Comparison to Dobson and Brewer}

In order to assess the newly derived SAOZ V2 data set, comparisons were performed using two reference ground-based UV ozone spectrophotometers collocated with SAOZ instruments: a Dobson at OHP and a Brewer at Sodankyla.

\subsubsection{Dobson at OHP}

The instrument is the Dobson \#085 operating at this station since 1983. A comparison of the total ozone columns measured by the Dobson and SAOZ (V2 retrieval) spectrometers is presented in Fig. 6. The difference Dobson-SAOZ showed in the past a systematic seasonal variation with a summer maximum, but of amplitude larger than that expected from the temperature dependence of the UV cross-sections only. According to Van Roozendael et al. (1998), it can also originate in the seasonal AMF variation not taken into account in the operational SAOZ retrievals. Consistent with this, the replacement of the SAOZ constant AMF by AMF LUTs reduces the amplitude of the seasonal Dobson-SAOZ difference from $6.9 \%$ to $3.2 \%$ (see Fig. 7). After applying this correction, the correlation of the Dobson-SAOZ V2 difference with ECMWF temperature indicates a dependence of the difference Dobson-SAOZ V2 of $0.25 \pm 0.02 \% /{ }^{\circ} \mathrm{C}$ at $50 \mathrm{hPa}$ and $0.20 \pm 0.01 \% /{ }^{\circ} \mathrm{C}$ at $30 \mathrm{hPa}$, or $0.18 \% /{ }^{\circ} \mathrm{C}$ at $30 \mathrm{hPa}$ using the NCEP temperature. The $30 \mathrm{hPa}$ temperature is more relevant at OHP since it corresponds better to the altitude of the maximum of ozone concentration. After correction for the temperature dependence at $30 \mathrm{hPa}$, the amplitude of the seasonal variation decreases to $1.2 \%$ with a yearly mean bias of $-1.1 \pm 3.7 \%$. This $0.18 \% /{ }^{\circ} \mathrm{C}$ temperature dependence is significantly larger than the $0.13 \% /{ }^{\circ} \mathrm{C}$ calculated by Komhyr et al. (1993) for the Dobson AD pair from the Bass and Paur ozone absorption cross sections (Paur and Bass, 1985), the $0.11 \% /{ }^{\circ} \mathrm{C}$ proposed by Van Roozendael et al. (1998) from Malicet et al. (1995) cross sections, or even the $0.02 \% /{ }^{\circ} \mathrm{C}$ of Burrows et al. (1999) as summarized by Scarnato et al. (2009). However, it is very similar to the $0.21 \% /{ }^{\circ} \mathrm{C}$ found with TOMS and OMI-TOMS.

Aside from a possible underestimation of the temperature dependence of the absorption cross sections at low temperature, another possible additional contribution to the seasonal variation of the difference with $\mathrm{SAOZ}$ could be the influence of tropospheric ozone to which, in contrast to Dobson direct sun observations, SAOZ is less sensitive. As displayed later in Fig. 15, the tropospheric ozone column at OHP shows a systematic seasonality of about 15 DU amplitude with a summer maximum, which might explain the remaining seasonal cycle of 1-1.5\% amplitude in the Dobson-SAOZ difference. Moreover, the Dobson instrument has internal stray light that produces an error with a SZA dependence, which is more pronounced at high ozone values. However, the magnitude of this effect is difficult to estimate, but it can also contribute to the residual seasonal cycle of the Dobson-SAOZ differences.

In summary, the $3.2 \%$ residual seasonal amplitude of the Dobson-SAOZ V2 difference at OHP can be partly explained by a known temperature dependence of the absorption crosssections at Dobson wavelengths not taken into account in the Dobson retrievals and varying between $0.11-0.13 \% /{ }^{\circ} \mathrm{C}$ according to laboratory measurements and $0.18 \% /{ }^{\circ} \mathrm{C}$ in the 


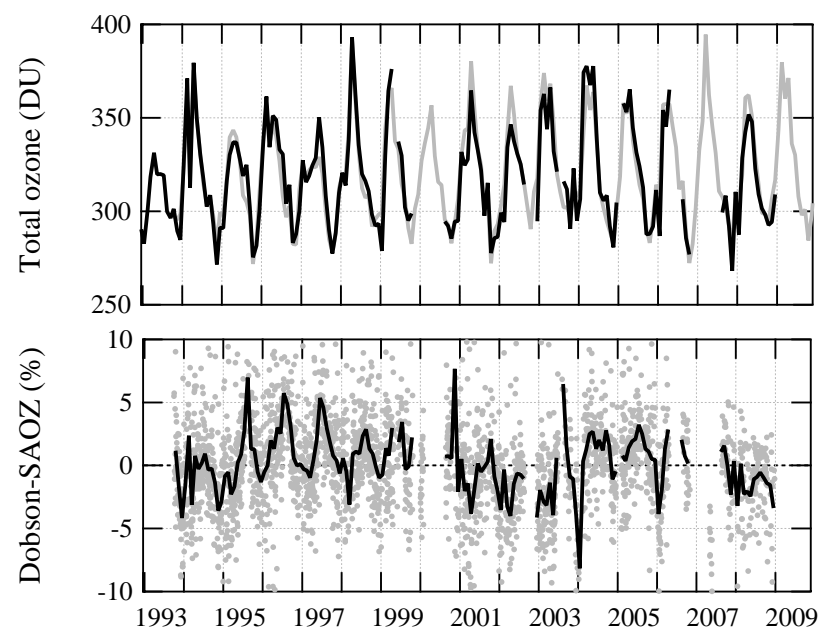

Fig. 6. Comparison between Dobson (black line) and SAOZ V2 (grey line) total ozone columns at OHP (upper plot). The relative difference Dobson-SAOZ V2 appears on the lower plot (grey dots: daily; black lines: monthly mean). SAOZ data in 1992-1993 are removed because of the Mount Pinatubo eruption. The difference shows a systematic seasonal cycle, and small systematic offsets between periods of several years as well as sporadic jumps on some months. Since they do not correlate with changes in the satelliteSAOZ difference at OHP they cannot be attributed to SAOZ.

present study, and by uncertainties in the ozone profile seasonal variation in the TV8 climatology, particularly in the troposphere. The mean $1 \%$ low bias of the SAOZ compared to Dobson is within the uncertainties of absolute crosssections used by both instruments.

\subsubsection{Brewer MKII at Sodankyla}

The Brewer and the SAOZ instruments in Sodankyla were already compared in 1990-91 (Kyrö, 1993; Van Roozendael et al., 1998). The SAOZ showed a systematic bias varying from $-9 \pm 5 \%$ if only Brewer measurements at $\mathrm{SZA}<60^{\circ}$ were considered and $+2 \%$ using all Brewer data. The seasonal cycle of the ratio between the Brewer and SAOZ measurements was highly correlated with the temperature at $50 \mathrm{hPa}$, but at a rate of $0.34 \% /{ }^{\circ} \mathrm{C}$, exceeding largely the $0.07 \% /{ }^{\circ} \mathrm{C}$ Brewer temperature dependence derived by Kerr et al. (1988) from the ozone cross sections of Paur and Bass (1985). At that time, no explanation was found for this discrepancy but the SAOZ retrieval was the V1 version based on the use of a constant AMF derived from a mean winter ozone profile. Figure 8 shows the Brewer and SAOZ V2 series of ozone column over Sodankyla since 1990 and the corresponding relative difference. The winter Brewer zenith-sky observations are ignored since displaying large drops as well as the 1992 SAOZ data due to the large aerosols loading changes associated to the Mount Pinatubo eruption. Asides from these periods, the Brewer values are larger than those of SAOZ

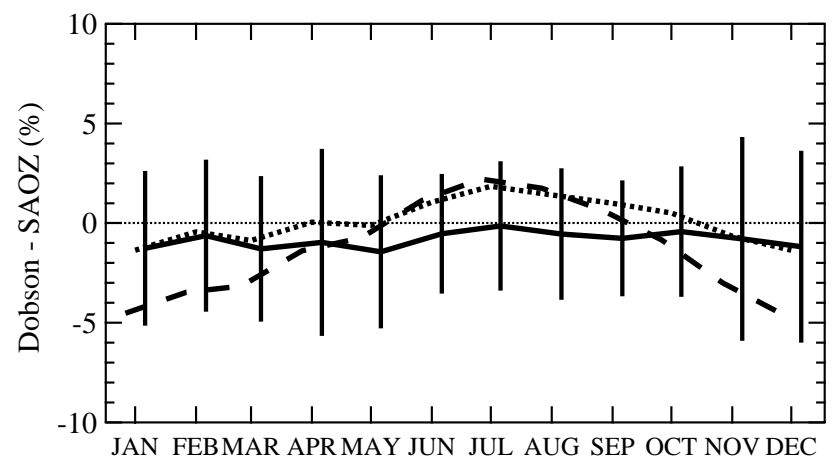

Fig. 7. Seasonal variation of the Dobson-SAOZ relative difference at OHP (dashed line: SAOZ V1, dotted line: SAOZ V2, solid line: Dobson corrected for temperature).

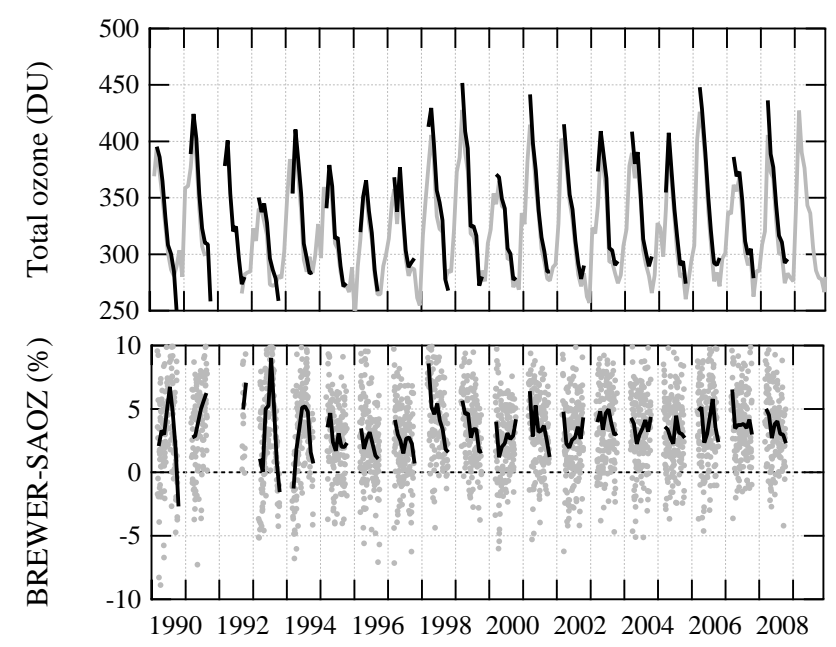

Fig. 8. Comparison between Brewer (black line) and SAOZ V2 (grey line) total ozone columns at Sodankyla. The relative difference Brewer-SAOZ V2 appears on the lower plot (grey dots: daily; black lines: monthly mean). SAOZ data in 1992-1993 are removed because of the Pinatubo eruption. Because of the polar night, Brewer measurements are absent during the winter. Small systematic offsets sometimes also appear, e.g., after 1997 and 2001.

by $3-4 \%$ on average, showing sometimes large deviations in October or March, i.e. at the beginning and the end of the winter. Figure 9 shows the average seasonal cycle of the difference. The change from SAOZ V1 to SAOZ V2 decreases the amplitude of the seasonal cycle from $4 \%$ to $2.4 \%$, providing an explanation to Kyrö (1993) interrogation. The correlation with ECMWF temperature indicates a dependence of the Brewer-SAOZ difference of $0.06 \pm 0.01 \% /{ }^{\circ} \mathrm{C}$ at $50 \mathrm{hPa}$ and of $0.05 \pm 0.01 \% /{ }^{\circ} \mathrm{C}$ at $30 \mathrm{hPa}$, the first one being most relevant at this latitude. After correction for the temperature dependence at $50 \mathrm{hPa}$, the amplitude of the seasonal variation decreases to $1.4 \%$ and the mean bias is $2.7 \pm 3.4 \%$. The coefficient of $0.06 \% /{ }^{\circ} \mathrm{C}$ is very consistent with the $0.07 \% /{ }^{\circ} \mathrm{C}$ and $0.08 \% /{ }^{\circ} \mathrm{C}$ estimated from Paur and 
Bass (1985) cross-sections by Kerr et al. (1988) and Scarnato et al. (2009), respectively, but smaller than the $0.09 \% /{ }^{\circ} \mathrm{C}$ of Kerr et al. (2002) from the same data but using different sets of temperature, or the $0.13 \% /{ }^{\circ} \mathrm{C}$ derived by Scarnato et al. (2009) from the Malicet et al. (1995) ozone crosssections. However, Scarnato et al. (2009) have shown that these coefficients depend on the instrument, the temperature range, and on the method of calculation from laboratory cross-sections. In addition, Savastiouk and McElroy (2010) have estimated that a change from Paur and Bass (1985) to Malicet et al. (1995) absorption cross-sections would make the Brewer data lower by $3 \%$ on average, that is in full agreement with SAOZ V2.

In summary, the difference between Brewer and SAOZ in Sodankyla can be fully explained by a temperature dependence of $0.06 \% /{ }^{\circ} \mathrm{C}$ and the $3 \%$ mean bias between them by the uncertainty in the ozone absorption cross-sections used in the Brewer retrieval.

\subsection{Comparison to satellite observations}

Six total ozone satellite data series are available since the beginning of the deployment of the SAOZ network in 1988: the TOMS V8 series from Nimbus-7, Meteor-3, and Earth Probe between 1989 and 2005, available from the NASA GSFC database (http://toms.gsfc.nasa.gov, Wellemeyer et al., 2004); the GOME-GDP4 observations from 1995 to 2003 for all stations and until present for the European sector after the failure of the onboard data recorder, available from the operational ESA GDP4 level 2 (http://wdc. dlr.de/sensors.gome/gdp4/; Van Roozendael et al., 2006); the SCIAMACHY-TOSOMI columns since 2002, available from the ESA - KNMI TEMIS site (http://www.temis.nl/ protocols/o3col/overpass_scia.html; Eskes et al., 2005), the SCIAMACHY off-line version 3 (OL3) retrievals available from the ftp site ftp-ops-dp.eo.esa.int, and the AURA OMITOMS and OMI-DOAS collection 3 retrievals since 2004 available from the NASA AVDC (http://avdc.gsfc.nasa.gov; Veefkind et al., 2006; Kroon et al., 2008). All the data used here are overpass total ozone columns above each station within a $300 \mathrm{~km}$ radius. Eight SAOZ stations, those showing the longest data time-series and continuous observations throughout the year, have been selected for the present comparison (see Table 5): three in the Arctic (Scoresbysund, Zhigansk, and Sodankyla), one at northern mid-latitude (Observatoire de Haute Provence), two at the southern tropics (Reunion Island and Bauru), one at the southern mid-latitude (Kerguelen) and one in the Antarctic (Dumont d'Urville). Because of the perturbation of the SAOZ zenith-sky total ozone measurements by the volcanic aerosols injected in the stratosphere by the eruption of Mount Pinatubo in 1991, the measurements performed between October 1991 and October 1992 have been ignored.

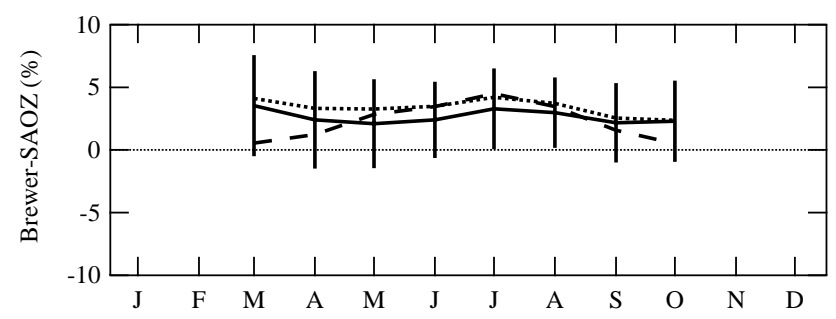

Fig. 9. Seasonal variation of the Brewer-SAOZ relative difference at Sodankyla (dashed line: SAOZ V1, dotted line: SAOZ V2, solid line: Brewer corrected for temperature).

Table 5. List of the SAOZ stations used in the study.

\begin{tabular}{lll}
\hline Station & Location & $\begin{array}{l}\text { Time } \\
\text { coverage }\end{array}$ \\
\hline ScoresbySund (SCO) & $71^{\circ} \mathrm{N}, 22^{\circ} \mathrm{W}$ & $1991-$ \\
Sodankyla (SOD) & $67^{\circ} \mathrm{N}, 27^{\circ} \mathrm{E}$ & $1990-$ \\
Zhigansk (ZHI) & $67^{\circ} \mathrm{N}, 123^{\circ} \mathrm{E}$ & $1991-$ \\
Observatoire de Haute Provence (OHP) & $44^{\circ} \mathrm{N}, 6^{\circ} \mathrm{E}$ & $1992-$ \\
Reunion Island (REU) & $21^{\circ} \mathrm{S}, 55^{\circ} \mathrm{E}$ & 1993 \\
Bauru (BAU) & $22^{\circ} \mathrm{S}, 49^{\circ} \mathrm{W}$ & 1995 \\
Kerguelen (KER) & $49^{\circ} \mathrm{S}, 70^{\circ} \mathrm{E}$ & $1995-$ \\
Dumont d'Urville (DDU) & $67^{\circ} \mathrm{S}, 140^{\circ} \mathrm{E}$ & $1988-$ \\
\hline
\end{tabular}

\subsubsection{V2 versus V1 SAOZ data sets}

As an example, monthly mean total ozone column and relative difference satellite-SAOZ V2 at OHP since 1995 for TOMS and GOME-GDP4 (the two longest satellite records) are presented in Fig. 10. The difference shows a systematic seasonal variation with a summer maximum. The amplitude of the seasonal cycle of the difference is larger with TOMS $(4.7 \%)$ than with GOME-GDP4 (1.2\%).

Figure 11 depicts the change between SAOZ V1 and V2 in the difference satellite-SAOZ at Sodankyla, OHP, Bauru and Dumont d'Urville. The use of V2 instead of V1 reduces the amplitude of the seasonal cycle of the difference with TOMS from $10.8 \%$ to $6.3 \%$ at Sodankyla and from $8.0 \%$ to $4.7 \%$ at OHP, and from $4.6 \%$ to $4.3 \%$ and $4.9 \%$ to $1.2 \%$ for the same stations with GOME-GDP4. The use of SAOZ V2 has a limited impact in Bauru (tropics), where the amplitude of the relative difference varies from $1.7 \%$ to $1.5 \%$ with TOMS and from $3.5 \%$ to $3.0 \%$ with GOME-GDP4, but decreases the mean total ozone by about $3 \%$. The same feature is found at Dumont d'Urville where the seasonal cycles is reduced only from 12.4 to $10.2 \%$ and 4.2 to $3.5 \%$ with TOMS and GOME, respectively, but the mean total ozone is decreased by $5 \%$ with SAOZ V2.

Table 6 summarizes the change in the seasonal cycle of the satellite-SAOZ difference for all selected stations and satellites. The replacement of the SAOZ V1 by the V2 version 
Table 6. Amplitude (\%) of the seasonal cycle of the relative differences satellite $-\mathrm{SAOZ}(\mathrm{V} 1 / \mathrm{V} 2)$. See Table 5 for the meaning of the abbreviations of the stations.

\begin{tabular}{lrrrrrr}
\hline Station & TOMS & GOME & SCIA-TOSOMI & SCIA-OL3 & OMI-TOMS & OMI-DOAS \\
\hline SCO & $8.8 / 5.0$ & $5.2 / 4.6$ & $9.3 / 12.2$ & $5.8 / 5.1$ & $3.9 / 2.4$ & $5.9 / 6.7$ \\
ZHI & $8.2 / 4.8$ & $5.3 / 4.0$ & $9.7 / 15.2$ & $3.8 / 2.6$ & $6.0 / 8.4$ & $6.1 / 10.2$ \\
SOD & $10.8 / 6.3$ & $4.6 / 4.3$ & $2.8 / 5.8$ & $7.7 / 3.5$ & $6.3 / 4.0$ & $2.2 / 4.4$ \\
OHP & $8.0 / 4.7$ & $4.9 / 1.2$ & $3.0 / 2.8$ & $6.3 / 3.1$ & $7.7 / 3.4$ & $4.1 / 2.0$ \\
REU & $2.1 / 1.4$ & $4.4 / 3.5$ & $2.2 / 1.8$ & $2.7 / 2.6$ & $3.1 / 2.6$ & $1.9 / 1.8$ \\
BAU & $1.7 / 1.5$ & $3.5 / 3.0$ & $2.4 / 3.1$ & $3.5 / 3.0$ & $3.6 / 3.0$ & $2.2 / 2.8$ \\
KER & $3.9 / 2.8$ & $1.7 / 2.0$ & $1.8 / 3.2$ & $1.9 / 1.5$ & $2.2 / 1.7$ & $2.3 / 3.5$ \\
DDU & $12.4 / 10.2$ & $4.2 / 3.5$ & $6.2 / 6.7$ & $3.2 / 2.9$ & $8.8 / 7.0$ & $4.3 / 5.0$ \\
\hline
\end{tabular}
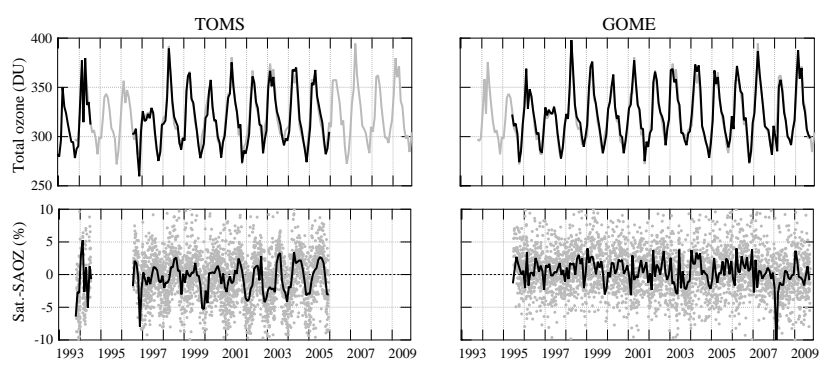

Fig. 10. Example of comparison between SAOZ V2 and satellite overpass total ozone at OHP. Top: monthly mean total ozone (grey line: SAOZ; black line: satellite), bottom: satellite-SAOZ relative difference (grey dots: daily; black lines: monthly mean). Left: TOMS, right: GOME-GDP4.

reduces on average the amplitude of the seasonal cycle of differences with TOMS, GOME, SCIA-OL3, and OMI-TOMS although systematic seasonal cycles still remain, of particularly large amplitude at high latitude. However, there are satellites for which the change from V1 to V2 increases the amplitude of the cycle, particularly SCIA-TOSOMI and OMI-DOAS at high latitude. This comes from larger uncertainties in some satellite retrievals at large SZA at the beginning and the end of the winter period, even if all satellite data have been uniformly limited to $\mathrm{SZA}<84^{\circ}$. The yearly mean AMF used in the SAOZ V1 retrieval is thus not the only parameter responsible for the seasonal cycle of the satelliteSAOZ and other parameters are implied. As already shown by Lambert et al. (1999), parameters displaying systematic seasonal cycles which could potentially affect the retrievals are: the temperature of the stratosphere and the SZA of satellite measurements, showing both a summer maximum, and the seasonal variation of the ozone column which presents a maximum in spring at mid- and high latitude.
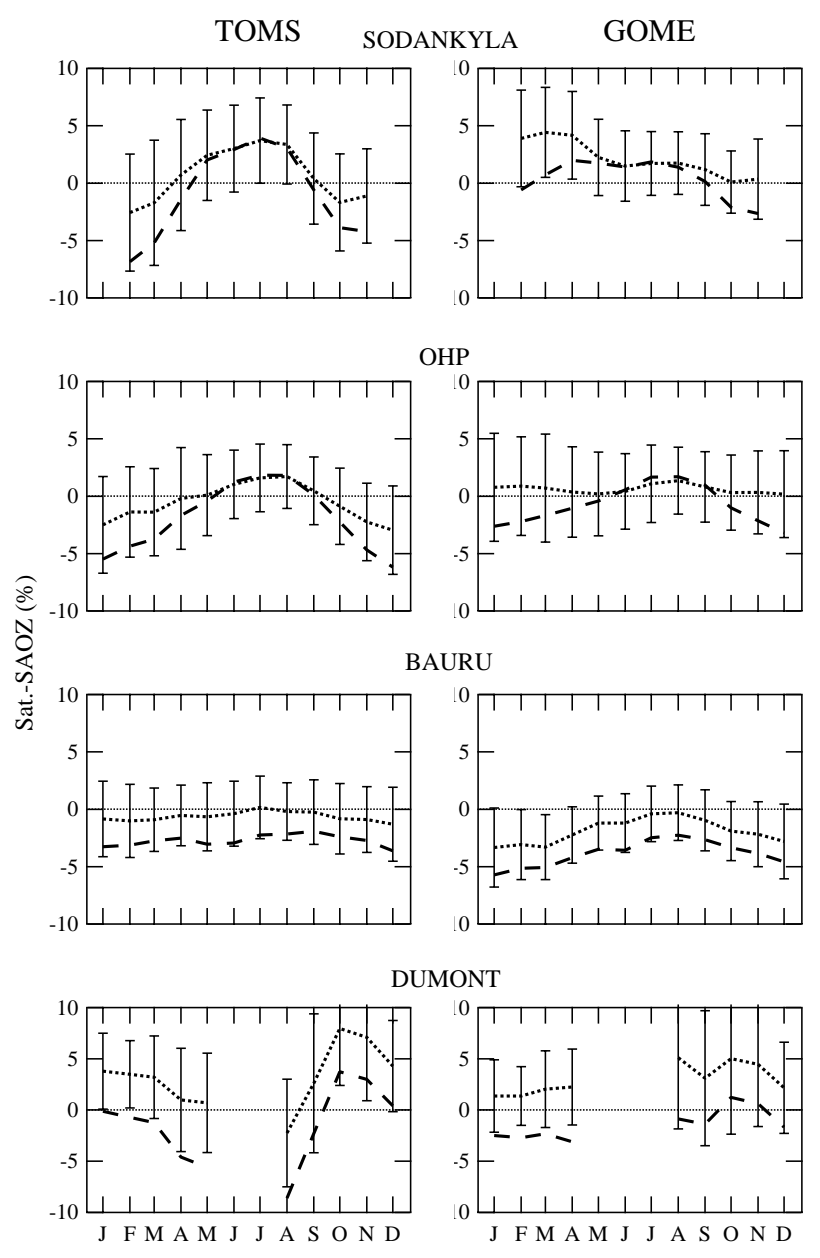

Fig. 11. Seasonal variation of the satellite-SAOZ relative difference (dashed lines: SAOZ V1, dotted lines: SAOZ V2). From top to bottom: Sodankyla, OHP, Bauru, and Dumont d'Urville. Left: TOMS, right: GOME-GDP4. The error bars correspond to the $1 \sigma$ deviations, which increase during the winter, particularly at high latitude. 
Table 7. Temperature dependence of satellite-SAOZ V2 relative difference at 50 and $30 \mathrm{hPa}\left(\right.$ in $\% /{ }^{\circ} \mathrm{C}$ ).

\begin{tabular}{lrr}
\hline Satellite & $50 \mathrm{hPa}$ & $30 \mathrm{hPa}$ \\
\hline TOMS & $+0.21 \pm 0.003$ & $+0.24 \pm 0.003$ \\
GOME-GDP4 & $+0.06 \pm 0.004$ & $+0.08 \pm 0.004$ \\
SCIA-TOSOMI & $+0.09 \pm 0.006$ & $+0.14 \pm 0.006$ \\
SCIA-OL3 & $+0.11 \pm 0.004$ & $+0.12 \pm 0.004$ \\
OMI-TOMS & $+0.21 \pm 0.004$ & $+0.16 \pm 0.004$ \\
OMI-DOAS & $+0.00 \pm 0.005$ & $+0.00 \pm 0.005$ \\
\hline
\end{tabular}

Table 8. SZA dependence of satellite-SAOZ V2 relative difference at $50 \mathrm{hPa}: b \times \mathrm{SZA}+c \times \mathrm{SZA}^{3}$.

\begin{tabular}{lrr}
\hline Satellite & $b$ & $c\left(\times 10^{-6}\right)$ \\
\hline TOMS & +0.02 & -1.7 \\
GOME-GDP4 & +0.06 & -1.8 \\
SCIA-TOSOMI & -0.01 & +16.2 \\
SCIA-OL3 & +0.00 & +4.0 \\
OMI-TOMS & +0.00 & +6.7 \\
OMI-DOAS & +0.02 & +7.3 \\
\hline
\end{tabular}

\subsubsection{Stratospheric temperature, SZA, and ozone column dependencies}

The influence of these parameters has been investigated by correlating the satellite-SAOZ difference with daily ECMWF temperature at $50 \mathrm{hPa}$ and $30 \mathrm{hPa}, \mathrm{SZA}$ at the location of the satellite measurements, and ozone total column. The correlation was performed on daily measurements from all stations together (sunrise-sunset average in case of SAOZ). For removing the systematic mean biases between the stations discussed in Sect. 4.2.3, the average bias of each station has been set to zero at $210 \mathrm{~K}$ and $50^{\circ} \mathrm{SZA}$. As an example, Fig. 12 depicts the correlation between the difference between TOMS and SAOZ and SCIA-TOSOMI and SAOZ with temperature at $50 \mathrm{hPa}$ on the left, and SZA on the right, after removing the satellite measurements at SZA $>84^{\circ}$ where they are known as less reliable. Since not significant, the dependence on total ozone columns is not shown. The calculation involves more than 30000 data points. These two satellites have been chosen here because showing the largest temperature (TOMS) and SZA (SCIA-TOSOMI) dependencies. TOMS displays a linear temperature dependence of $0.21 \% /{ }^{\circ} \mathrm{C}$ resulting in a seasonal amplitude of more than $10 \%$ amplitude in the Antarctic and a negligible SZA dependence of $0.01 \% /{ }^{\circ} \mathrm{SZA}$, which represents only $0.4 \%$ of amplitude in seasonality. In contrast, SCIA-TOSOMI shows a temperature dependence of $0.08 \% /{ }^{\circ} \mathrm{C}$ only, but a large and non-linear SZA dependence, approximated by a cubic law, of $-0.01 \%{ }^{\circ} \mathrm{SZA}+16.2 \times 10^{-6} \% /^{\circ} \mathrm{SZA}^{3}$, leading to a sea-
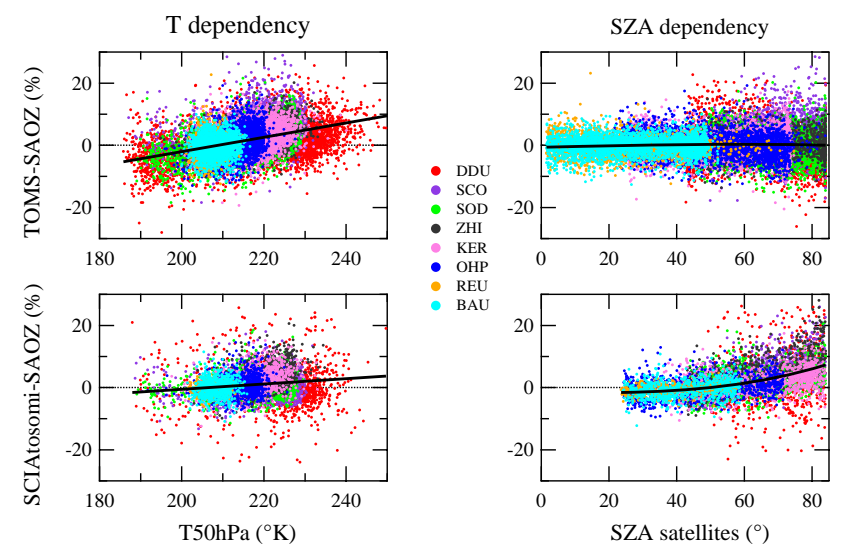

Fig. 12. Correlation between daily satellite-SAOZ difference and ECMWF temperature at $50 \mathrm{hPa}$ (left), and SZA of satellite measurements (right) for the height SAOZ stations altogether. Top: TOMS; Bottom: SCIA-TOSOMI.

sonal variation of total ozone of $9 \%$ amplitude at high latitude. Such SZA dependence of a nadir-viewing satellite instrument is coming from the increasing altitude of the sunlight scattering layer at increasing SZA, not properly taken into account in the retrieval. Note that a confusion between SZA and temperature in the correlations shown in Fig. 12 is not possible, since (1) the first is peaking at the solstice and the second in the mid-summer, and (2) the amplitude of the temperature variation is limited to $15^{\circ} \mathrm{C}$ in the tropics, while that of SZA is varying by about $45^{\circ}$.

The results of the same calculations for all satellites are summarized in Tables 7 and 8 . In case of the temperature, the results at 50 and $30 \mathrm{hPa}$ were found very similar. But since the peak ozone concentration at high latitude is around $50 \mathrm{hPa}$, this level was chosen in the corrections below. Remarkably, TOMS and OMI-TOMS, which are using the same wavelengths $(317.5-331.2 \mathrm{~nm})$ and the same retrieval algorithm, show the same temperature dependence of $0.21 \% /{ }^{\circ} \mathrm{C}$, while GOME, SCIA-TOSOMI and SCIA-OL3 measuring in the $325-335 \mathrm{~nm}$ spectral band are less sensitive to temperature (between 0.06 and $0.11 \% /{ }^{\circ} \mathrm{C}$ ). OMI-DOAS is totally insensitive to temperature. Since $\mathrm{SAOZ}$ measures in the visible Chappuis band where the ozone absorption cross-sections do not show significant temperature dependence (Voigt et al., 2001; Brion et al., 2004), the observed temperature dependencies of the difference with satellites could be attributed to the UV absorption cross-sections used by the satellites. Their temperature dependence is indeed larger at shorter wavelengths. However the amplitude of the effect reported here is unexpected since a correction for the temperature dependence of the ozone cross-sections is applied in the satellite retrievals algorithms. More work is therefore needed to better understand the origin of the discrepancy. 


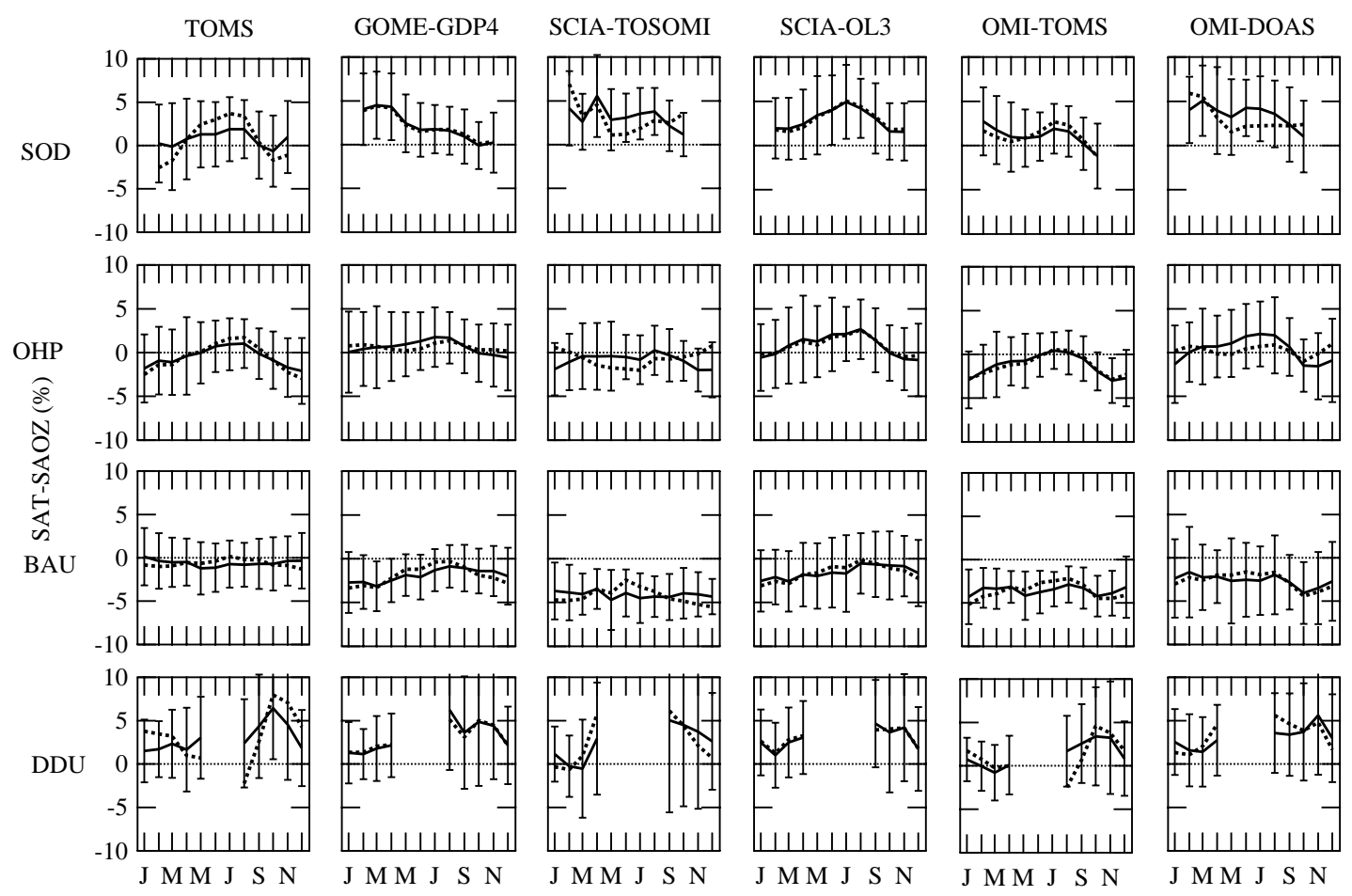

Fig. 13. Seasonal variations before (dotted lines) and after (solid lines) temperature correction. From top to bottom: Sodankyla, OHP, Bauru and Dumont d'Urville. From left to right: TOMS, GOME-GDP4, SCIAMACHY-TOSOMI, SCIAMACHY-OL3, OMI-TOMS, and OMI-DOAS.

Regarding SZA, SCIA-TOSOMI shows the largest nonlinear dependence $\left(16.2 \times 10^{-6} \% /^{\circ} \mathrm{SZA}^{3}\right)$, while GOME displays a linear change of $0.06 \% /^{\circ} \mathrm{SZA}(2.4 \%$ in term of seasonal amplitude), followed by SCIA-OL3, OMI-TOMS and OMI-DOAS but with a non-linear dependence, leading to a seasonal cycle with an amplitude varying between 1.6 and $2.9 \%$ amplitude. TOMS does not show significant sensitivity to SZA. As in case of temperature, since SAOZ is always measuring between $86-91^{\circ}$ SZA, the SZA dependence of the difference with satellites must be attributed to the latter.

Figure 13 shows the residual seasonal variation of the satellite - SAOZ V2 differences for four stations after correction of the satellite data for their temperature and SZA dependencies, and Table 9, the residual amplitude of the seasonal cycle before and after applying the correction. On average, the correction reduces the amplitude of the seasonal cycle, particularly with TOMS, OMI-TOMS, SCIA-TOSOMI. There are some exceptions, e.g. with GOME, SCIA-OL3 and OMI-DOAS at OHP, and GOME and SCIA-OL3 at Dumont d'Urville. But often, the seasonal cycles are not totally removed. A systematic summer maximum could be still seen with all satellites at OHP and systematic seasonal cycles with various shapes at polar stations. It should be noted that the above corrections have no impact on yearly mean biases.

Figure 14 shows the latitudinal variation of these mean biases and the standard deviation of the difference with SAOZ

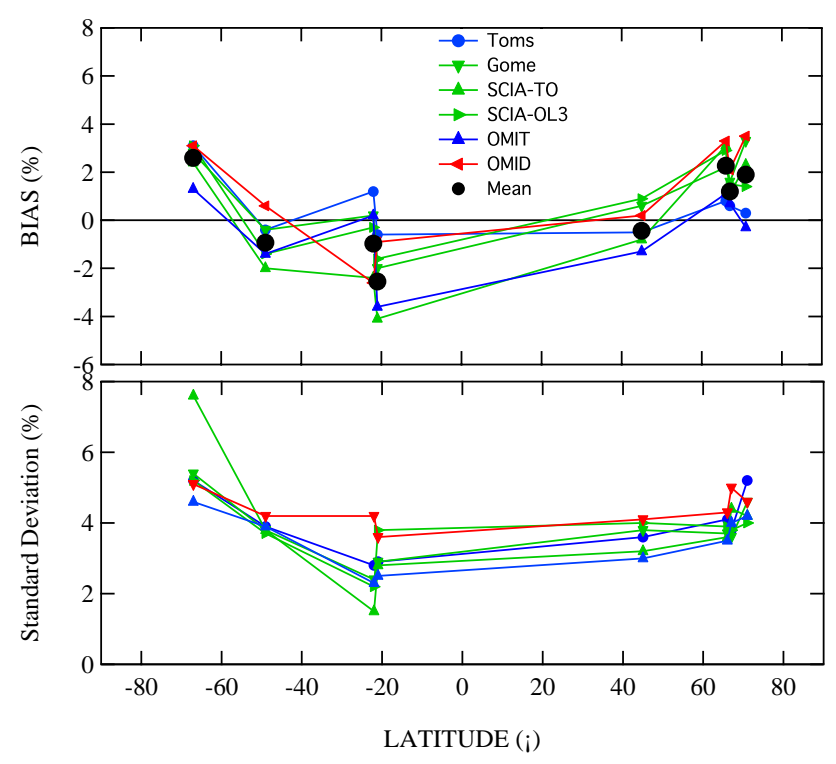

Fig. 14. Latitudinal variation of mean bias (top) and standard deviation (bottom) of the relative difference satellite - SAOZ V2. All satellites measurements are showing very similar mean biases with SAOZ, as well as dispersion, with the exception of SCIA-TOSOMI in Dumont d'Urville for an unknown reason. 
Table 9. Residual amplitude of the satellite-SAOZ V2 difference seasonal cycle (in \%) before/after temperature (50 hPa) and SZA correction. See Table 5 for the meaning of the abbreviations of the stations.

\begin{tabular}{lrrrrrr}
\hline Station & TOMS & GOME & SCIA-TOSOMI & SCIA-OL3 & OMI-TOMS & OMI-DOAS \\
\hline SCO & $5.0 / 3.8$ & $4.6 / 4.6$ & $12.2 / 7.3$ & $5.1 / 4.8$ & $2.4 / 3.9$ & $6.7 / 4.2$ \\
ZHI & $4.8 / 2.7$ & $4.0 / 4.0$ & $15.2 / 9.5$ & $2.6 / 2.3$ & $8.4 / 6.5$ & $10.2 / 7.8$ \\
SOD & $6.3 / 2.5$ & $4.3 / 4.6$ & $5.8 / 4.4$ & $3.5 / 3.4$ & $4.0 / 3.9$ & $4.4 / 4.1$ \\
OHP & $4.7 / 3.1$ & $1.2 / 2.3$ & $2.8 / 2.2$ & $3.1 / 3.5$ & $3.4 / 3.4$ & $2.0 / 3.7$ \\
REU & $1.4 / 1.2$ & $3.5 / 2.8$ & $1.8 / 1.2$ & $2.6 / 1.6$ & $2.6 / 1.8$ & $1.8 / 1.3$ \\
BAU & $1.5 / 1.3$ & $3.0 / 2.3$ & $3.1 / 1.2$ & $3.0 / 2.1$ & $3.0 / 1.4$ & $2.8 / 2.4$ \\
KER & $2.8 / 1.2$ & $2.0 / 1.5$ & $3.2 / 4.4$ & $1.5 / 1.2$ & $1.7 / 1.5$ & $3.5 / 1.1$ \\
DDU & $10.2 / 4.9$ & $3.8 / 5.1$ & $6.8 / 5.6$ & $2.9 / 3.6$ & $7.1 / 4.2$ & $4.5 / 4.2$ \\
\hline
\end{tabular}

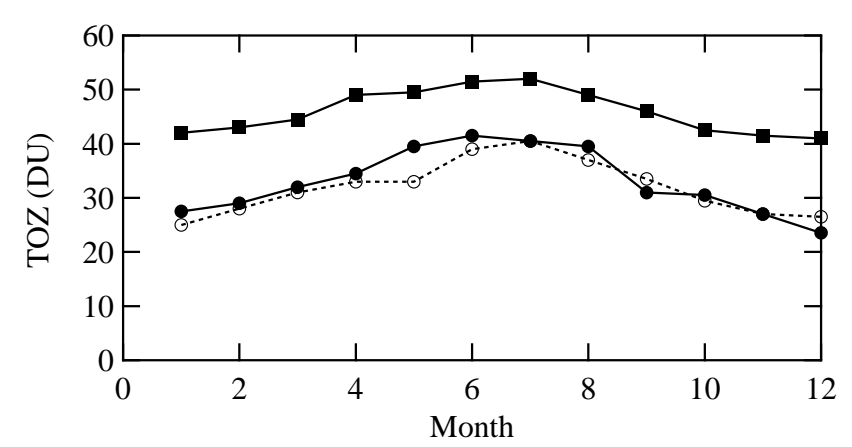

Fig. 15. Tropospheric ozone column in OHP derived from OMI (open circles), ECC sondes (filled circles), and TV8 climatology (filled squares).

at each station, the corresponding values being summarised in Table 10. The biases at each station are very similar for all satellites. They increase at high latitude and, remarkably, they are more negative in Bauru than in Reunion although the two stations are at the same latitude. The mean standard deviation of about $3-4 \%$ of the difference with SAOZ is also very similar with all satellites, but larger with SCIA-TOSOMI in Dumont d'Urville for an unknown reason.

The similarity of the biases between SAOZ on the one hand and all satellites on the other hand implies that they are to be attributed mostly to SAOZ. They can be related in part to unknown pseudo-systematic uncertainties in SAOZ slant column measurements (quoted to $3 \%$ in Table 4), to uncertainties in the determination of the residual amount in the reference spectrum, and finally to possible systematic errors in the AMFs used for converting slant into vertical columns. As shown by the comparison between SAOZ V1 and V2, the latter is a very sensitive parameter. Two possible sources of biases have been identified: the influence of tropospheric ozone assumed to be constant in a latitude band, and possible systematic differences between ozone profiles measured above a given station and those from the TV8 zonal mean climatology.

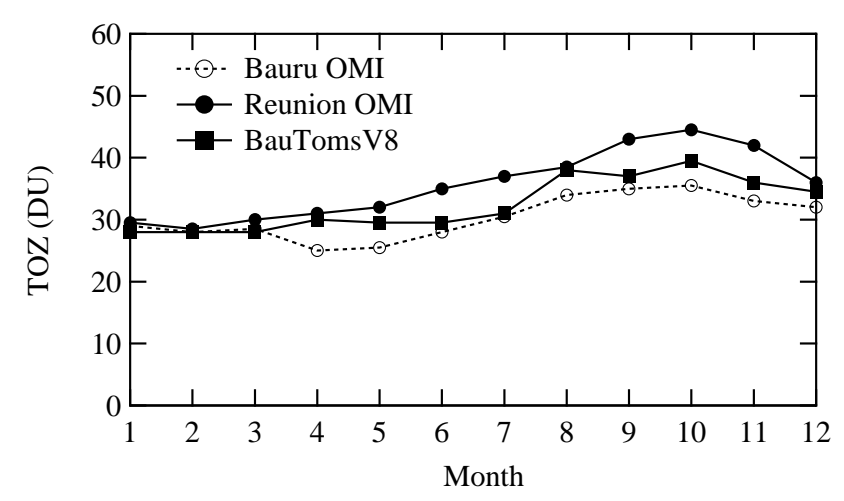

Fig. 16. Tropospheric ozone column derived from OMI in Bauru (open circles) and Reunion (filled circles) and TV8 climatology (filled squares).

\subsubsection{Air mass factor biases}

There are indications that the biases in Fig. 14 and residual seasonal variations in Fig. 13 come from differences between ozone profiles over a specific station and the TOMS V8 climatology used for calculating $\mathrm{O}_{3}$ AMFs: the still small summer maximum in the difference after correction of satellite measurements for temperature and SZA dependencies, of between 2.2-3.7\% magnitude for example at OHP, the systematic bias jump of $1.7-3.4 \%$ between Bauru and Reunion, and the average $1.3-3.1 \%$ larger biases and seasonal variations at polar stations compared to the mid- and tropical altitudes.

A seen in Fig. 15, tropospheric ozone above OHP shows a seasonal cycle of 15 DU amplitude with a summer maximum, while the TV8 climatology overestimates the mean value by about $10 \mathrm{DU}$ and underestimates the amplitude of the seasonal cycle by $7-8 \mathrm{DU}$. This is enough for explaining the remaining seasonal cycle of $2 \%$ amplitude of the TOMS - SAOZ and OMI-TOMS - SAOZ differences seen in Fig. 13. The same argument applies to the systematic difference of about $2 \%$ between Bauru and Reunion, present with all satellites. This is consistent with the difference of 
Table 10. Bias and $1 \sigma$ dispersion of the relative difference satellite-SAOZ V2 (in \%) after temperature (50 hPa) and SZA correction. See Table 5 for the meaning of the abbreviations of the stations.

\begin{tabular}{lrrrrrrr}
\hline Station & TOMS & GOME & SCIA-TOSOMI & SCIA-OL3 & OMI-TOMS & OMI-DOAS & MEAN \\
\hline SCO & $+0.3 \pm 5.2$ & $+3.3 \pm 4.6$ & $+2.3 \pm 4.2$ & $+1.4 \pm 4.0$ & $-0.3 \pm 4.2$ & $+3.5 \pm 4.6$ & $1.9 \pm 4 / 5$ \\
ZHI & $+0.6 \pm 3.8$ & $+1.6 \pm 3.6$ & $+1.1 \pm 4.4$ & $+1.5 \pm 3.8$ & $+0.7 \pm 4.0$ & $+2.1 \pm 5.0$ & $1.2 \pm 4.1$ \\
SOD & $+0.8 \pm 4.2$ & $+2.2 \pm 3.7$ & $+3.1 \pm 3.6$ & $+2.9 \pm 3.9$ & $+1.1 \pm 3.5$ & $+3.3 \pm 4.3$ & $2.3 \pm 3.9$ \\
OHP & $-0.5 \pm 3.6$ & $+0.6 \pm 3.8$ & $-0.8 \pm 3.2$ & $+0.9 \pm 4.0$ & $-1.3 \pm 3.0$ & $+0.2 \pm 4.1$ & $-0.4 \pm 3.6$ \\
REU & $+1.2 \pm 2.8$ & $+0.2 \pm 2.4$ & $-2.4 \pm 1.5$ & $-0.3 \pm 2.2$ & $+0.2 \pm 2.3$ & $-0.9 \pm 3.6$ & $-1.0 \pm 3.1$ \\
BAU & $-0.6 \pm 2.9$ & $-2.0 \pm 2.9$ & $-4.1 \pm 2.8$ & $-1.6 \pm 3.8$ & $-3.6 \pm 2.5$ & $-2.6 \pm 4.2$ & $-2.5 \pm 3.2$ \\
KER & $-0.4 \pm 3.9$ & $-0.4 \pm 3.8$ & $-2.0 \pm 3.8$ & $-1.4 \pm 3.7$ & $-1.4 \pm 3.9$ & $+0.6 \pm 4.2$ & \\
DDU & $+3.1 \pm 5.2$ & $+2.8 \pm 5.4$ & $+2.4 \pm 7.6$ & $+3.1 \pm 5.2$ & $+1.3 \pm 4.6$ & $+3.1 \pm 5.1$ & $2.6 \pm 4.8$ \\
\hline
\end{tabular}

tropospheric ozone of about $10 \mathrm{DU}$ (see Fig. 16) between the two stations derived by Ziemke et al. (2006) by subtracting the MLS stratospheric ozone from the OMI total column, and also consistent with the wave number one longitudinal tropospheric ozone distribution reported by the SHADOZ ozonesondes (Thompson et al., 2003), displaying a maximum over Africa and the Indian Ocean. Finally, the still remaining relatively large seasonal cycles and larger biases during the winter-spring vortex season at polar latitudes are consistent with the presence of differences between AMFs derived from the TV8 zonal mean ozone profiles and those measured locally by radio-sondes, as shown in Fig. 4 for Ny-Ålesund and Dumont d'Urville, or by the comparison between TOMS and TV8 total column ozone displaying a maximum difference at high latitude (McPeters et al., 2007).

Overall, after correcting satellite measurements for their temperature and SZA dependencies, the largest remaining cause of differences between them and SAOZ would come from the zonal mean ozone profiles used for calculating the AMF which does not always represent the longitudinal and seasonal variations of ozone concentration in the troposphere and the stratosphere.

\section{Conclusions}

The NDACC UV-visible Working Group has made recommendations on the spectral analysis settings and AMF calculation for the retrieval of total ozone columns from groundbased zenith-sky UV-visible observations. The aim of these recommendations is to improve the homogeneity of the visible total ozone measurements delivered to the NDACC database. The main change with respect to the settings utilized so far, is the use of $\mathrm{O}_{3}$ AMF LUTs based on the TOMS $\mathrm{V} 8 \mathrm{O}_{3}$ profile climatology, which allows accounting for the dependence of the AMF on the latitudinal and seasonal variations of the ozone vertical profile. The calculated LUTs, only suitable for background aerosols conditions, depend on latitude, day of year, $\mathrm{O}_{3}$ column, wavelength, $\mathrm{SZA}$, surface albedo, and station altitude. The main sources of uncertainty in the $\mathrm{O}_{3}$ AMF calculation have been identified as the use of an $\mathrm{O}_{3}$ profiles climatology instead of observational data, the choice of the aerosol extinction profile and the radiative transfer model, the surface albedo, and most sensitive, the presence of clouds. Taking into account these uncertainties, the precision on the $\mathrm{O}_{3}$ AMFs has been estimated to $4.7 \%$, which, combined with systematic errors results in a total accuracy in ozone retrievals of $5.9 \%$.

For evaluating the change in the $\mathrm{SAOZ}$ performances when applying the NDACC recommendations, the full SAOZ data set has been reprocessed and compared to collocated reference ground-based Dobson and Brewer measurements at OHP and Sodankyla respectively, as well as to satellite overpass observations from the TOMS, GOMEGDP4, SCIAMACHY-TOSOMI, SCIAMACHY-OL3, OMITOMS, and OMI-DOAS data products for a selection of eight stations.

We find that the use of the $\mathrm{O}_{3}$ AMF LUTs reduces the difference between Dobson, Brewer, and SAOZ total ozone measurements. Nevertheless small systematic seasonal variations of the difference with $\mathrm{SAOZ}$ still remain, originating in the temperature dependence of the ozone absorption cross sections in the UV not taken into account in the Dobson and Brewer retrievals and possibly also in seasonal cycles of tropospheric ozone only partly represented in the TV8 profile climatology used for calculating the $\mathrm{O}_{3}$ AMF LUTs. When corrected for the temperature dependence, the average difference with daily SAOZ total ozone columns is reduced to $-0.8 \pm 3.8 \%$ with the Dobson in OHP and to $1.9 \pm 3.2 \%$ with the Brewer in Sodankyla, which is within current uncertainties in the $\mathrm{O}_{3}$ absorption cross-sections of the three instruments.

Regarding the comparison with satellites, the agreement is also significantly improved when using the new SAOZ data set (called version V2). However, some systematic seasonal variations still remain in the difference satellite $-\mathrm{SAOZ} \mathrm{V2.}$ They largely originate from stratospheric temperature and SZA dependencies in the satellite retrievals. The sensitivity to temperature is particularly large in the $317-331 \mathrm{~nm}$ 
wavelengths range of the TOMS and OMI-TOMS retrievals and similar to that observed with the Dobson. This effect is also present but with a smaller amplitude in the GOME, SCIA-TOSOMI and SCIA-OL3 measurements in the 325$335 \mathrm{~nm}$ range and in the Brewer observations. It is absent in OMI-DOAS retrievals. Since the visible Chappuis bands used by $\mathrm{SAOZ}$ are not sensitive to temperature, these dependencies might indicate an inadequate correction for the temperature sensitivity of the ozone absorption cross-sections in the UV in the satellite retrievals. One should note that the large sensitivity, particularly of the TOMS and OMI-TOMS columns, to stratospheric temperature is unexpected since, in contrast to Dobson and Brewer, a correction for this effect is included in the retrieval algorithms. We have no further explanation for that.

The SZA dependence is particularly large in case of SCIATOSOMI and is also present, but with a smaller amplitude, in the SCIA-OL3, OMI-TOMS and OMI-DOAS retrievals. Since the SAOZ measurements are always performed at around $90^{\circ} \mathrm{SZA}$ throughout the year, this dependence must be attributed to the satellite retrievals. However, even after correcting satellites data for temperature and SZA dependencies, systematic biases and seasonal features still remain, with a larger amplitude in polar regions. They are tentatively attributed to (i) longitudinal modulations and seasonal variations of tropospheric ozone columns not represented in the $\mathrm{TV}_{8} \mathrm{O}_{3}$ zonal mean climatology, (ii) uncertainties in the TV8 stratospheric ozone profiles at high latitude during the ozone depletion winter and spring season, known to exist from the comparisons with AMF derived from sondes or between TV8 and TOMS total ozone (McPeters et al., 2007), and (iii) uncertainties in the absolute absorption cross-sections at all wavelengths. After applying the LUT AMF to SAOZ and correcting the satellites for the temperature and SZA dependencies, the amplitude of the seasonal difference between them and SAOZ decreases to less than 2$4 \%$ at mid-latitude and in the tropics and to $3-9 \%$ in polar regions, while the mean bias is varying from -1 to $-2 \%$ at mid-latitude and in the tropics, to +1 to $+2 \%$ in polar regions.

Overall, although further improvements could be expected regarding the accuracy of ozone absorption cross-sections and their temperature dependence and ozone profile climatologies, the application of the NDACC UV-visible Working Group recommendations, together with the correction for the temperature and SZA dependencies of UV ground-based and satellite observations, leads to a significantly improved consistency of total ozone long-term series between the various satellite and ground-based instruments, allowing more accurate identification of possible natural or anthropogenic changes in the ozone layer.

Acknowledgements. The authors thank the many SAOZ, Brewer and Dobson operators in stations without whom the long series of data used in this paper would not have been available as well as agencies supporting NDACC activities: INSU/CNRS, CNES, IPEV. This work was supported by the ESA Multi-Taste, EC
GEOmon, and Belgian PRODEX SECPEA projects. The authors are also thankful to the PIs of the lidar and ECC sondes $\mathrm{O}_{3}$ profile data used in this study and downloaded from the NDACC database: P. von der Gathen (AWI), G. Hansen and K. Stebel (NILU), S. Godin-Beekmann, G. Ancellet, and F. Goutail (LATMOS/CNRS), A. Redondas (INME-IZO), F. Posny (Université de la Réunion), G. Bodeker (NIWA), and D. Swart (RIVM). N. Theys (BIRA-IASB) is acknowledged for calculating time-series of tropopause height at various NDACC stations.

Edited by: M. Dameris

\section{References}

Anderson, S. M. and Mauersberger, K.: Laser measurements of ozone absorption cross sections in the Chappuis Band, Geophys. Res. Lett., 19, 933-936, 1992.

Bhartia, P. K., Wellemeyer, C. G., Taylor, S. L., Nath, N., and Gopolan, A.: Solar Backscatter (SBUV) Version 8 profile algorithm, in: Proceedings of the Quadrennial Ozone Symposium 2004, Athens, Greece, edited by: Zerefos, C., ISBN 960-630103-6, 295-296, 2004.

Bogumil, K., Orphal, J., Homann, T., Voigt, S., Spietz, P., Fleischmann, O. C., Vogel, A., Hartmann, M., Bovensmann, H., Frerik, J., and Burrows, J. P.: Measurements of molecular absorption spectra with the SCIAMACHY Pre-Flight Model: Instrument characterization and reference spectra for atmospheric remote sensing in the $230-2380 \mathrm{~nm}$ region, J. Photochem. Photobiol. A, 157, 167-184, 2003.

Brion, J., Chakir, A., Charbonnier, J., Daumont, D., Parisse, C., and Malicet, J.: Absorption Spectra Measurements for the Ozone Molecule in the 350-830 nm Region, J. Atm. Chem., 30, 291299, doi:10.1023/A:1006036924364, 2004.

Burrows, J. P., Richter, A., Dehn, A., Deters, B., Himmelmann, S., Voigt, S., and Orphal, J.: Atmospheric Remote-sensing reference data from GOME - 2.Temperature-dependent absorption crosssections of $\mathrm{O}_{3}$ in the 231-794 nm range, J. Quant. Spectrosc. Ra., 61(4), 509-517, 1999.

Chance, K. and Spurr, R. J. D.: Ring effect studies: Rayleigh scattering including molecular parameters for rotational Raman scattering, and the Fraunhofer spectrum, Appl. Optics, 36, 52245230, 1997.

Coldewey-Egbers, M., Weber, M., Lamsal, L. N., de Beek, R., Buchwitz, M., and Burrows, J. P.: Total ozone retrieval from GOME UV spectral data using the weighting function DOAS approach, Atmos. Chem. Phys., 5, 1015-1025, doi:10.5194/acp5-1015-2005, 2005.

Eskes, H. J. and Boersma, K. F.: Averaging kernels for DOAS totalcolumn satellite retrievals, Atmos. Chem. Phys., 3, 1285-1291, doi:10.5194/acp-3-1285-2003, 2003.

Eskes, H. J., van der A, R. J., Brinksma, E. J., Veefkind, J. P., de Haan, J. F., and Valks, P. J. M.: Retrieval and validation of ozone columns derived from measurements of SCIAMACHY on Envisat, Atmos. Chem. Phys. Discuss., 5, 44294475, doi:10.5194/acpd-5-4429-2005, 2005.

Fayt, C. and Van Roozendael, M.: WinDOAS 2.1 Software User Manual, available at: http://uv-vis.aeronomie.be/software/ WinDOAS, 2009. 
Grainger, J. and Ring, J.: Anomalous Fraunhofer line profiles, Nature, 193, p. 762, 1962.

Hendrick, F., Van Roozendael, M., Kylling, A., Petritoli, A., Rozanov, A., Sanghavi, S., Schofield, R., von Friedeburg, C., Wagner, T., Wittrock, F., Fonteyn, D., and De Mazière, M.: Intercomparison exercise between different radiative transfer models used for the interpretation of ground-based zenith-sky and multi-axis DOAS observations, Atmos. Chem. Phys., 6, 93-108, doi:10.5194/acp-6-93-2006, 2006.

Hendrick, F., Johnston, P. V., Kreher, K., Hermans, C., De Mazière, M., and Van Roozendael, M.: One decade trend analysis of stratospheric $\mathrm{BrO}$ over Harestua $\left(60^{\circ} \mathrm{N}\right)$ and Lauder $\left(44^{\circ} \mathrm{S}\right)$ reveals a decline, Geophys. Res. Lett., 35, L14801, doi:10.1029/2008GL034154, 2008.

Høiskar, B. A. K., Dahlback, A., Vaughan, G., Braathen, G. O., Goutail, F., Pommereau, J.-P., and Kivi, R.: Interpretation of ozone measurements by ground-based visible spectroscopy - A study of the seasonal dependence of airmass factors for ozone based on climatology data, J. Quant. Radiat. Transfer, 57(4), 569-579, 1997.

Hofmann, D., Bonasoni, P., De Mazière, M., Evangelisti, F., Sarkissian, A., Giovanelli, G., Goldman, A., Goutail, F., Harder, J., Jakoubek, R., Johnston, P., Kerr, J., McElroy, T., McKenzie, R., Mount, G., Pommereau, J.-P., Simon, P., Solomon, S., Stutz, J., Thomas, A., Van Roozendael, M., and Wu, E.: Intercomparison of UV/visible spectrometers for measurements of stratospheric $\mathrm{NO}_{2}$ for the Network for the Detection of Stratospheric Change, J. Geophys. Res., 100, 16765-16791, 1995.

$\mathrm{Hu}, \mathrm{Y}$. X. and Stamnes, K.: An accurate parameterization of the radiative properties of water clouds suitable for use in climate models, J. Climate, 6, 728-742, 1993.

Kerr, J. B.: New methodology for deriving total ozone and other atmospheric variables from Brewer spectrophotometer direct sun spectra, J. Geophys. Res., 107, 4731, doi:10.1029/2001JD001227, 2002.

Kerr, J. B., Asbridge, I. A., and Evans, W. F. J.: Intercomparison of total ozone measured by the Brewer and Dobson spectrophotometers at Toronto, J. Geophys. Res., 93, 11129-11140, 1988.

Koelemeijer, R. B. A., de Haan, J. F., and Stammes, P.: A database of spectral surface reflectivity in the range $335-772 \mathrm{~nm}$ derived from 5.5 years of GOME observations, J. Geophys. Res., 108(D2), 4070, doi:10.1029/2002JD002429, 2003.

Komhyr, W.D, Mateer, C. L., and Hudson, R. D.: Effective Bass and Paur 1985 ozone absorption coefficients for the use with Dobson ozone spectrophotometrers, J. Geophys. Res., 98, 20451-20465, 1993.

Kreher, K., Johnston, P. V., Wood, S. W., and Platt, U.: Groundbased measurements of tropospheric and stratospheric $\mathrm{BrO}$ at $\mathrm{Ar}-$ rival Heights ( $\left.78^{\circ} \mathrm{S}\right)$, Antarctica, Geophys. Res. Lett., 24, 30213024, 1997.

Kroon, M., Veefkind, J. P., Sneep, M., McPeters, R. D., Bhartia, P. K., and Levelt, P. F.: Comparing OMI-TOMS and OMIDOAS total ozone column data, J. Geophys. Res., 113, D16S28, doi:10.1029/2007JD008798, 2008.

Kurucz, R. L., Furenlid, I., and Brault, J. T. L.: Solar flux atlas from 296 to 1300 nm, National Solar Observatory Atlas, Sunspot, New Mexico, 1984.

Kyrö, E.: Intercomparison of total ozone data from Nimbus-7 Toms, the Brewer UV spectrophotometer and SAOZ UV-Visible spec- trometer at high latitudes observatory, Sodankyla, Geophys. Res. Lett. 20, 571-574, 1993.

Lambert, J.-C., Van Roozendael, M., De Mazière, M., Simon, P. C., Pommereau, J.-P., Goutail, F., Sarkissian, A., and Gleason, J. F.: Investigation of pole-to-pole performances of spaceborne atmospheric chemistry sensors with the NDSC, J. Atmos. Sci., 56, 176-193, 1999.

Lamsal, L. N., Weber, M., Labow, G., and Burrows, J. P. : Influence of ozone and temperature climatology on the accuracy of satellite total ozone retrieval, J. Geophys. Res., 112, D02302, doi:10.1029/2005JD006865, 2007.

Malicet, J., Daumont, D., Charbonnier, J., Parisse, C., Chakir, A., and Brion, J.: Ozone UV spectroscopy. II. Absorption crosssections and temperature dependence, J. Atmos. Chem., 21, 263 273, 1995.

Mayer, B. and Kylling, A.: Technical note: The libRadtran software package for radiative transfer calculations - description and examples of use, Atmos. Chem. Phys., 5, 1855-1877, doi:10.5194/acp-5-1855-2005, 2005.

McKenzie, R. L., Johnston, P. V., McElroy, C. T., Kerr, J. B., and Solomon, S.: Altitude distributions of stratospheric constituents from ground-based measurements at twilight, J. Geophys. Res., 96, 15499-15512, 1991.

McPeters, R. D., Labow, G. J., and Logan, J. A.: Ozone climatological profiles for satellite retrieval algorithms, J. Geophys. Res., 112, D05308, doi:10.1029/2005JD006823, 2007.

Orphal, J.: A critical review of the absorption cross-sections of $\mathrm{O}_{3}$ and $\mathrm{NO}_{2}$ in the $240-790 \mathrm{~nm}$ region, J. Photochem. Photobiol. A: Chemistry, 157, 185-209, 2003.

Paur, R. J. and Bass, A. M.: The ultraviolet cross-sections of ozone, II, Result and temperature dependence, in: Atmospheric Ozone, edited by: Zerefos, C. and Ghazi, A., D. Reidel, Dordrecht, 611616, 1985.

Platt, U. and Stuz, J.: Differential Optical Absorption Spectroscopy (DOAS), Principles and Applications, ISBN 978-3-540-21193-8, Springer, Berlin-Heidelberg, 2008.

Pommereau, J.-P. and Goutail, F.: $\mathrm{O}_{3}$ and $\mathrm{NO}_{2}$ ground-based measurements by visible spectrometry during arctic winter and spring 1988, Geophys. Res. Lett., 15, 891-894, 1988.

Pommereau, J.-P. and Piquard, J.: Ozone, nitrogen dioxide and aerosol vertical distributions by UV-visible solar occultation from balloons, Geophys. Res. Lett., 13, 1227-1230, 1994.

Richter, A., Eisinger, M., Ladstätter Weißenmayer, A., Wittrock, F., and Burrows, J. P.: DOAS zenith-sky observations: 2.Seasonal variations of $\mathrm{BrO}$ over Bremen (53 N) 1994-1995, J. Atmos. Chem., 32, 83-99, 1999.

Roscoe, H. K., Squires, J. A. C., Oldham, D. J., Sarkissian, A., Pommereau, J.-P., and Goutail, F.: Improvements to the accuracy of zenith-sky measurements of total ozone by visible spectrometers, J. Quant. Spectrosc. Ra., 52(5), 639-648, 1994.

Roscoe, H. K., Johnston, P. V., Van Roozendael, M., Richter, A., Sarkissian, A., Roscoe, J., Preston, K. E., Lambert, J.-C., Hermans, C., Decuyper, W., Dzienus, S., Winterrath, T., Burrows, J. P., Goutail, F., Pommereau, J.-P., D’Almeida, E., Hottier, J., Coureul, C., Didier, R., Pundt, I., Bartlett, L. M., McElroy, C. T., Kerr, J. E., Elokhov, A., Giovanelli, G., Ravegnani, F., Premuda, M., Kostadinov, I., Erle, F., Wagner, T., Pfeilsticker, K., Kenntner, M., Marquard, L. C., Gil, M., Puentedura, O., Yela, M., Arlander, D. W., Kastad Hoiskar, B. A., Tellefsen, C. W., Karlsen 
Tørnkvist, K., Heese, B., Jones, R. L., Aliwell, S. R., and Freshwater, R. A.: Slant column measurements of $\mathrm{O}_{3}$ and $\mathrm{NO}_{2}$ during the NDSC intercomparison of zenith-sky UV-visible spectrometers in June 1996, J. Atmos. Chem., 32, 281-314, 1999.

Roscoe, H. K., Van Roozendael, M., Fayt, C., du Piesanie, A., Abuhassan, N., Adams, C., Akrami, M., Cede, A., Chong, J., Clmer, K., Friess, U., Gil Ojeda, M., Goutail, F., Graves, R., Griesfeller, A., Grossmann, K., Hemerijckx, G., Hendrick, F., Herman, J., Hermans, C., Irie, H., Johnston, P. V., Kanaya, Y., Kreher, K., Leigh, R., Merlaud, A., Mount, G. H., Navarro, M., Oetjen, H., Pazmino, A., Perez-Camacho, M., Peters, E., Pinardi, G., Puentedura, O., Richter, A., Schnhardt, A., Shaiganfar, R., Spinei, E., Strong, K., Takashima, H., Vlemmix, T., Vrekoussis, M., Wagner, T., Wittrock, F., Yela, M., Yilmaz, S., Boersma, F., Hains, J., Kroon, M., Piters, A., and Kim, Y. J.: Intercomparison of slant column measurements of $\mathrm{NO}_{2}$ and $\mathrm{O}_{4}$ by MAX-DOAS and zenith-sky UV and visible spectrometers, Atmos. Meas. Tech., 3, 1629-1646, doi:10.5194/amt-3-1629-2010, 2010.

Rothman, L. S., Jacquemart, D., Barbe, A., Chris Benner, D., Birk, M., Brown, L. R., Carleer, M. R., Chackerian Jr. C., Chance, K., Coudert, L. H., Dana, V., Devi, V. M., Gamache, R. R., Goldman, A., Jucks, K. W., Maki, A. G., Massie, S. T., Orphal, J., Perrin, A., Rinsland, C. P., Smith, M. A. H., Tennyson, J., Tolchenov, R. N., Toth, R. A., Vander Auwera, J., Varanasi, P., and Wagner, G.: The Hitran 2004 molecular spectroscopic database, J. Quant. Spectrosc. Ra., 96, 139-204, 2005.

Rozanov, A., Rozanov, V., Buchwitz, M., Kokhanovsky, A., and Burrows, J. P.: SCIATRAN 2.0. A new radiative transfer model for geophysical applications in the $175-2400 \mathrm{~nm}$ spectral region, Adv. Space Res., 36(5), 1015-1019, 2005.

Sarkissian, A., Pommereau, J.-P., and Goutail, F.: Identification of polar stratospheric clouds from the ground by visible spectrometry, Geophys. Res. Lett., 18, 779-782, 1991.

Sarkissian, A., Roscoe, H. K., Fish, D., Van Roozendael, M., Gil, M., Chen, H. P., Wang, P., Pommereau, J.-P., and Lenoble, J.: Ozone and $\mathrm{NO}_{2}$ AMF for zenith sky spectrometer: Intercomparison of calculations with different radiative transfer model, Geophys. Res. Lett., 22, 1113-1116, 1995.

Sarkissian, A., Vaughan, G., Roscoe, H. K., Bartlett, L. M., O'Connor, F. M., Drew, D. G., Hughes, P. A., and Moore, D. M.: Accuracy of measurements of total ozone by a SAOZ ground-based zenith-sky visible spectrometer, J. Geophys. Res., 102(D1), 1379-1390, 1997.

Savastiouk, V. and McElroy, T.: The effect of change of BP to DBM ozone absorption cross-sections on total ozone from Brewer, ICAGO Ozone Theme Meeting, Geneva, Switzerland, available at: http://igaco-o3.fmi.fi/ACSO/presentations_2010/ ground-based/OTM_2010_Savastiouk.pdf, 23-25 March 2010.

Scarnato, B., Staehelin, J., Peter, T., Gröbner, J., and Stübi, R.: Temperature and slant path effects in Dobson and Brewer total ozone measurements, J. Geophys. Res., 114, D24303, doi:10.1029/2009JD012349, 2009.

Shettle, E. P.: Models of aerosols, clouds, and precipitation for atmospheric propagation studies, in: NATO AGARD Conference Proceedings No. 454: Atmospheric propagation in the UV, visible, IR and mm-region and related system aspects, Neuilly sur Seine, France, 1989.

Solomon, S., Schmeltekopf, A. L., and Sanders, R. W.: On the in- terpretation of zenith-sky absorption measurements, J. Geophys. Res., 92, 8311-8319, 1987.

Solomon, S., Sanders, R. W., Carroll, M. A., and Schmeltekopf, A. L.: Visible and near-ultraviolet spectroscopy at McMurdo station, Antarctica, 5. Diurnal variation of $\mathrm{OClO}$ and $\mathrm{BrO}$, J. Geophys. Res., 94, 11393-11403, 1989.

Struthers, H., Kreher, K., Austin, J., Schofield, R., Bodeker, G., Johnston, P., Shiona, H., and Thomas, A.: Past and future simulations of $\mathrm{NO}_{2}$ from a coupled chemistry-climate model in comparison with observations, Atmos. Chem. Phys., 4, 2227-2239, doi:10.5194/acp-4-2227-2004, 2004.

Thompson, A. M., Witte, J. C., Oltmans, S. J., Schmidlin, F. J., Logan, J. A., Fujiwara, M., Kirchhoff, V. W. J. H., Posny, F., Coetzee, G. J. R., Hoegger, B., Kawakami, S., Ogawa, T., Fortuin, J. P. F., and Kelder, H. M.: Southern Hemisphere Additional Ozonesondes (SHADOZ) 1998-2000 tropical ozone climatology 2. Tropospheric variability and the zonal wave-one, J. Geophys. Res., 108(D2), 8241, doi:10.1029/2002JD002241, 2003.

Vandaele, A. C., Hermans, C., Simon, P. C., Carleer, M., Colin, R., Fally, S., Mérienne, M.-F., Jenouvrier, A., and Coquart, B.: Measurements of the $\mathrm{NO}_{2}$ absorption cross section from 42000 $\mathrm{cm}^{-1}$ to $10000 \mathrm{~cm}^{-1}(238-1000 \mathrm{~nm})$ at $220 \mathrm{~K}$ and $294 \mathrm{~K}, \mathrm{~J}$. Quant. Spectrosc. Ra., 59, 171-184, 1997.

Vandaele, A. C., Fayt, C., Hendrick, F., Hermans, C., Humbled, F., Van Roozendael, M., Gil, M., Navarro, M., Puentedura, O., Yela, M., Braathen, G., Stebel, K., Tørnkvist, K., Johnston, P., Kreher, K., Goutail, F., Mieville, A., Pommereau, J.-P., Khaikine, S., Richter, A., Oetjen, H., Wittrock, F., Bugarski, S., Frieß, U., Pfeilsticker, K., Sinreich, R., Wagner, T., Corlett, G., and Leigh, R.: An intercomparison campaign of ground-based UV-Visible measurements of $\mathrm{NO}_{2}, \mathrm{BrO}$, and $\mathrm{OClO}$ slant columns. Methods of analysis and results for $\mathrm{NO}_{2}$, J. Geophys. Res., 110, D08305, doi:10.1029/2004JD005423, 2005.

Van Roozendael, M., Peters, P., Roscoe, H. K., De Backer, H., Jones, A. E., Bartlett, L., Vaughan, G., Goutail, F., Pommereau, J.-P., Kyrö, E., Wahlstrom, C., Braathen, G., and Simon, P. C.: Validation of ground-based visible measurements of total ozone by comparison with Dobson and Brewer spectrophotometers, J. Atmos. Chem., 29, 55-83, 1998.

Van Roozendael, M., Loyola, D., Spurr, R., Balis, D., Lambert, J.-C., Livschitz, Y., Valks, P., Ruppert, T., Kenter, P., Fayt, C., and Zehner, C.: Ten years of GOME/ERS-2 total ozone data - The new GOME data Processor (GDP) version 4: 1 Algorithm description, J. Geophys. Res. 111, D14311, doi:10.1029/2005JD006375, 2006.

Vaughan, G., Roscoe, H. K., Bartlett, L. M., O'Connor, F., Sarkissian, A., Van Roozendael, M., Lambert, J.-C., Simon, P. C., Karlsen, K., Kaestad Hoiskar, B. A., Fish, D. J., Jones, R. L., Freshwater, R., Pommereau, J.-P., Goutail, F., Andersen, S. B., Drew, D. G., Hughes, P. A., Moore, D., Mellqvist, J., Hegels, E., Klupfel, T., Erle, F., Pfeilsticker, K., and Platt, U.: An intercomparison of ground-based UV-visible sensors of ozone and $\mathrm{NO}_{2}$, J. Geophys. Res., 102, 1411-1422, 1997.

Veefkind, J. P., de Haan, J. F., Brinksma, E. J., Kroon, M., and Levelt, P. F.: Total ozone from the Ozone Monitoring Instrument (OMI) using the OMI DOAS technique, IEEE T. Geosci. Remote, 44(5), 1239-1244, 2006.

Voigt, S., Orphal, J., Bogumil, K., and Burrows, J. P.: The temperature dependence (203-293 K) of the absorption cross-sections 
of $\mathrm{O}_{3}$ in the $230-850 \mathrm{~nm}$ region measured by Fourier-transform spectroscopy, J. Photochem. Photobiol. A, 143, 1-9, 2001.

Wagner, T., Burrows, J. P., Deutschmann, T., Dix, B., von Friedeburg, C., Frieß, U., Hendrick, F., Heue, K.-P., Irie, H., Iwabuchi, H., Kanaya, Y., Keller, J., McLinden, C. A., Oetjen, H., Palazzi, E., Petritoli, A., Platt, U., Postylyakov, O., Pukite, J., Richter, A., van Roozendael, M., Rozanov, A., Rozanov, V., Sinreich, R., Sanghavi, S., and Wittrock, F.: Comparison of box-airmass-factors and radiances for Multiple-Axis Differential Optical Absorption Spectroscopy (MAX-DOAS) geometries calculated from different UV/visible radiative transfer models, Atmos. Chem. Phys., 7, 1809-1833, doi:10.5194/acp-7-1809-2007, 2007.

Weber, M., Lamsal, L. N., Coldewey-Egbers, M., Bramstedt, K., and Burrows, J. P.: Pole-to-pole validation of GOME WFDOAS total ozone with groundbased data, Atmos. Chem. Phys., 5, 1341-1355, doi:10.5194/acp-5-1341-2005, 2005.
Wellemeyer, C. G., Bhartia, P. K., Taylor, S. L., Qin, W., and Ahn, C.: Version 8 Total Ozone Mapping Spectrometer (TOMS) Algorithm, in: Proceedings of the Quadrennial Ozone Symposium 2004, Athens, Greece, edited by: Zerefos, C., ISBN 960-630103-6, 635-636, 2004.

Ziemke, J. R., Chandra, S., Duncan, B. N., Froidevaux, L., Bhartia, P. K., Levelt, P. F., and Waters, J. W.: Tropospheric ozone determined from Aura OMI and MLS: Evaluation of measurements and comparison with the Global Modeling Initiative's Chemical Transport Model, J. Geophys. Res., 111, D19303, doi:10.1029/2006JD007089, 2006. 